\title{
Inventory of African desert dust events in the north-central Iberian Peninsula in 2003-2014 based on sun-photometer-AERONET and particulate-mass-EMEP data
}

\author{
Victoria E. Cachorro ${ }^{1}$, Maria A. Burgos ${ }^{1}$, David Mateos ${ }^{1}$, Carlos Toledano $^{1}$, Yasmine Bennouna ${ }^{1}$, Benjamín Torres ${ }^{1}$, \\ Ángel M. de Frutos ${ }^{1}$, and Álvaro Herguedas ${ }^{2}$ \\ ${ }^{1}$ Grupo de Óptica Atmosférica, Facultad de Ciencias, Universidad de Valladolid, Paseo Belén 7, CP 47011, Valladolid, Spain \\ ${ }^{2}$ Departamento de Control de Calidad y Cambio Climático, Consejería de Fomento y Medio Ambiente de la Junta de Castilla \\ y León, Valladolid, Spain
}

Correspondence to: Victoria E. Cachorro (chiqui@goa.uva.es)

Received: 15 January 2016 - Published in Atmos. Chem. Phys. Discuss.: 19 February 2016

Revised: 3 June 2016 - Accepted: 6 June 2016 - Published: 8 July 2016

Abstract. A reliable identification of desert dust (DD) episodes over north-central Spain is carried out based on the AErosol RObotic NETwork (AERONET) columnar aerosol sun photometer (aerosol optical depth, AOD, and Ångström exponent, $\alpha$ ) and European Monitoring and Evaluation Programme (EMEP) surface particulate-mass concentration $\left(\mathrm{PM}_{x}, x=10,2.5\right.$, and $\left.2.5-10 \mu \mathrm{m}\right)$ as the main core data. The impact of DD on background aerosol conditions is detectable by means of aerosol load thresholds and complementary information provided by HYSPLIT (Hybrid Single Particle Lagrangian Integrated Trajectory Model) air mass back trajectories, MODIS (Moderate Resolution Imaging Spectroradiometer) images, forecast aerosol models, and synoptic maps, which have been carefully reviewed by a human observer for each day included in the DD inventory. This identification method allows the detection of low and moderate DD intrusions and also of mixtures of mineral dust with other aerosol types by means of the analysis of $\alpha$. During the period studied (2003-2014), a total of 152 DD episodes composed of 418 days are identified. Overall, this means $\sim 13$ episodes and $\sim 35$ days per year with DD intrusion, representing $9.5 \%$ days year ${ }^{-1}$. During the identified DD intrusions, 19 daily exceedances over $50 \mu \mathrm{g} \mathrm{m}^{-3}$ are reported at the surface. The occurrence of DD event days during the year peaks in March and June, with a marked minimum in April and lowest occurrence in winter. A large interannual variability is observed showing a statistically significant temporal decreasing trend of $\sim 3$ days year $^{-1}$. The DD impact on the aerosol climatology is addressed by evaluating the DD contribution in magnitude and percent (in brackets) for AOD, $\mathrm{PM}_{10}, \mathrm{PM}_{2.5}$, and $\mathrm{PM}_{2.5-10}$, obtaining mean values of $0.015(11.5 \%), 1.3 \mu \mathrm{g} \mathrm{m}^{-3}$ (11.8\%), $0.55 \mu \mathrm{g} \mathrm{m}^{-3}$ (8.5\%) and $0.79 \mu \mathrm{g} \mathrm{m}^{-3}(16.1 \%)$, respectively. Annual cycles of the DD contribution for AOD and $\mathrm{PM}_{10}$ present two maxima one in summer $\left(0.03\right.$ and $2.4 \mu \mathrm{g} \mathrm{m}^{-3}$ for AOD in June and $\mathrm{PM}_{10}$ in August) and another in March (0.02 for AOD and $2.2 \mu \mathrm{g} \mathrm{m}^{-3}$ for $\mathrm{PM}_{10}$ ) - both displaying a similar evolution with exceptions in July and September. The seasonal cycle of the DD contribution to AOD does not follow the pattern of the total AOD (close to a bell shape), whereas both $\mathrm{PM}_{10}$ cycles (total and DD contribution) are more similar to each other in shape, with an exception in September. The interannual evolution of the DD contribution to AOD and $\mathrm{PM}_{10}$ has evidenced a progressive decrease. This decline in the levels of mineral dust aerosols can explain up to $30 \%$ of the total aerosol load decrease observed in the study area during the period 2003-2014. The relationship between columnar and surface DD contribution shows a correlation coefficient of 0.81 for the interannual averages. Finally, synoptic conditions during DD events are also analysed, observing that the north African thermal low causes most of the events $(\sim 53 \%)$. The results presented in this study highlight the relevance of the area studied since it can be considered representative of the clean background in the western Mediterranean Basin where DD events have a high impact on aerosol load levels. 


\section{Introduction}

Atmospheric aerosol particles play a key role in the radiation scattering and absorption physical processes that contribute to the Earth's radiative budget (Trenberth et al., 2009; Wild et al., 2013). Their impact on Earth's climate is represented by their direct radiative forcing (Haywood and Boucher, 2000; Boucher et al., 2013), but aerosols also act as cloud condensation nuclei modifying cloud properties and giving rise to a set of feedback processes that constitute the indirect radiative effect (Lohmann and Feichter, 2005; Lohmann et al., 2010; Boucher et al., 2013). All these aerosol climate effects have been enhanced due to anthropogenic aerosol particles (mainly sulfate and carbonaceous substances), which have increased the mean global temperature in the last century and have modified the atmospheric composition substantially (Boucher et al., 2013). Aerosol radiative properties, such as aerosol optical depth (AOD) or single scattering albedo (d'Almeida et al., 1991; Cachorro et al., 2000; Eck et al., 2010) are important issues to consider when studying the impact of atmospheric aerosol on climate.

Beside the climatological aspect of atmospheric aerosols, another element to be considered is their direct effect on air quality (Ganor et al., 2009; Kulmala et al., 2009; Querol et al., 2013). In environmental studies, particulate matter is mostly represented by its level of mass concentration at the surface represented by various size fractions $\left(\mathrm{PM}_{10}, \mathrm{PM}_{2.5}\right.$, $\mathrm{PM}_{1}$, etc., where the subscript indicates the upper cut-off of the aerodynamic diameter of particles and $\mathrm{PM}_{x}$ is used here as a general term referring to these fractions) and by the chemical speciation of its components: sulfates, nitrates, carbonaceous material, and minerals, among others. Aerosols can have a strong adverse impact on human health (e.g. Pope, 2000; Pérez et al., 2012) and ecosystems (Mahowald et al., 2010).

Desert or mineral dust aerosol is one of the main natural types of atmospheric aerosol particles, with a strong impact on the Earth system due to its worldwide distribution and temporal variability (Goudie and Middleton, 2006; Knippertz and Stuut, 2014; Viana et al., 2014). The injections of desert dust (DD) into the atmosphere, from the main two Sahara dust sources (Bodélé depression and eastern Mauritania) by different resuspension processes, can result in aerosol layers at high altitude being transported long distances to the Atlantic Ocean and Europe (e.g. Prospero, 1999; Prospero et al., 2002; Escudero et al., 2006, 2011; Engelstaedter and Washington, 2007; Knippertz and Todd, 2012; Guirado et al., 2014).

Our interest in this work focuses on atmospheric aerosol studies over the Iberian Peninsula (IP), which constitutes a peculiar area due to the large spatio-temporal variability in aerosol properties, types, and mixing processes as a result of the contrasting influences of the Atlantic Ocean, Mediterranean Sea, European continent, and the Saharan area. Based on sun-photometer data studies, different sectors of the IP, defined by their topography or geography, can exhibit different aerosol climatologies (Alados-Arboledas et al., 2003; Vergaz et al., 2005; Estellés et al. 2007; Toledano et al., 2007a; Obregón et al., 2012; Bennouna et al., 2013; Mateos et al., 2014a). In particular, the Sahara and Sahel desert areas are the most important natural sources of mineral aerosols for the IP. The closeness of the IP to the African continent intensifies the impact of desert dust events on the aerosol load, measured as the whole atmospheric column (AOD) and at the surface $\left(\mathrm{PM}_{x}\right)$. Different synoptic weather conditions and circulation patterns influence the arrival of desert dust intrusions in the IP, resulting in differences in the seasonal behaviour (Escudero et al., 2005, 2006; Toledano et al., 2007b; Basart et al., 2009; Valenzuela et al., 2012a; Pey et al., 2013a; Salvador et al., 2013, 2014). These intrusions are characterized by isolated or episodic events of short duration (around 2-3 days). However, episodes in summer months are longer and more frequent than in other seasons, so that often successive episodes are linked due to the recirculation of air masses producing feedback processes, which give rise to a long residence time of desert dust particles in the atmosphere when there is low precipitation (Rodríguez et al., 2002; Escudero et al., 2005). Therefore, desert dust aerosols are one of the most important types over the IP, having an important influence on the air quality and radiative properties, and hence their detection, quantification, and characterization are important research tasks.

There are different ways to approach the detection or identification of desert dust events depending on the objectives of each study. The detection depends on the different techniques used: surface measurements, remote sensing (satellite or ground-based), back-trajectory evaluation, aerosol models, or a combination of these. Air mass trajectories are one of the first and most used techniques to identify the origin of the transport of mineral dust aerosols to different regions worldwide (e.g. Hogan and Rosmond, 1991; Prospero et al., 2002; Kallos et al., 2003; Pace et al., 2006). Although there is abundant literature about mineral dust over southern Europe or the Mediterranean areas, most of the studies about detection, characterization, and/or the impact of desert dust aerosols are focused on case studies or particularly strong episodes: e.g. in Italy (e.g. Meloni et al., 2007; di Sarra et al., 2011; Bègue et al., 2012), Greece (e.g. Kaskaoutis et al., 2008), or the Iberian Peninsula (e.g. Lyamani et al., 2005; Cachorro et al., 2006, 2008; Pérez et al., 2006; GuerreroRascado et al., 2009; Córdoba-Jabonero et al., 2011). Few studies are based on long-term datasets of desert dust using different techniques, such as sun photometers (Toledano et al., 2007b; Valenzuela et al., 2012b), satellite sensors (Kaufman et al., 2005, Kaskaoutis et al., 2012; Gkikas et al., 2013, 2015), lidar measurements (Mona et al., 2006, 2014; Papayannis et al., 2008), or $\mathrm{PM}_{x}$ data (Escudero et al., 2005; Pey et al., 2013a; Salvador et al., 2013, 2014; Rodríguez et al., 2015). As can be seen from this list only recent studies 
contain long-term data sets and only in some of them is the net contribution to the aerosol load of DD evaluated.

The $\mathrm{PM}_{x}$ observations provided by different networks have constituted one of the most frequent tools for the establishment of DD inventories (e.g. Escudero et al., 2005; Pey et al., 2013a; Salvador et al., 2013, 2014) in order to evaluate their contribution to $\mathrm{PM}_{x}$ levels required by the $\mathrm{EU}$ directives. The EU 2008/50/EC directive (EC, 2008) on air quality establishes threshold values for the concentration of particles with an aerodynamic diameter below $10\left(\mathrm{PM}_{10}\right)$ and $2.5\left(\mathrm{PM}_{2.5}\right) \mu \mathrm{m}$ : an annual mean and $24 \mathrm{~h}$ mean of 40 and $50 \mu \mathrm{g} \mathrm{m}^{-3}$ for $\mathrm{PM}_{10}$ and an annual $\mathrm{PM}_{2.5}$ average of $25 \mu \mathrm{g} \mathrm{m}^{-3}$. In this sense it is necessary to know the contribution of natural and anthropogenic components to the total aerosol load. Therefore, the contribution of mineral dust in south Europe is important because of the link between $\mathrm{PM}_{10}$ exceedances and DD intrusions or outbreaks.

Once the identification of DD African aerosols is carried out, the next task is to quantify their contribution to the total aerosol load. The evaluation of the contribution of DD episodes to $\mathrm{PM}_{x}$ data is viable by means of a chemical speciation analysis (Rodríguez et al., 2001, 2002, 2015), but this method requires high manpower and has poor temporal sampling. Hence, in order to avoid this expensive technique, other methods have been developed using $\mathrm{PM}_{x}$ (Escudero et al., 2007; Ganor et al., 2009) and AOD data (Toledano et al., 2007b). As reported by Viana et al. (2010) and taking into account more recent publications (e.g. MAGRAMA, 2013, 2015), no more than three methods are currently used with $\mathrm{PM}_{x}$, including receptor models (Pey et al., 2013b; Belis et al., 2013). However, these techniques would need to be updated to the measuring site for DD contribution estimates. In a similar way columnar aerosol algorithms can facilitate the apportioning of the different aerosol types (Dubovik et al., 2002; O'Neill et al., 2003) to the total aerosol load.

The advantage of remote sensing techniques, such as sun photometry, for DD detection is the spectral information recorded by their AOD measurements and given by the Angström exponent, $\alpha$. This is a powerful tool in the identification and classification of the different aerosol types (Eck et al., 1999; Toledano et al., 2007a) but also allows "nearreal-time" processing of data by means of reasonably sophisticated algorithms (Dubovik et al., 2002; O'Neill et al., 2003) that retrieve aerosol properties. The evolutions of surface $\mathrm{PM}_{x}$ and columnar AOD differ in the seasonal cycles (see, e.g., Bennouna et al., 2014; Mateos et al., 2015), and hence their DD impact can also present some discrepancies in that cycle. The $\mathrm{PM}_{x}$ sampling used here is based on daily filter records (see Aas et al., 2013), while sun photometers provide instantaneous measurements of the columnar load but their sampling is limited to daytime cloud-free conditions (Toledano et al., 2007a, b).

The usefulness of a DD inventory is that it opens the possibility of the evaluation of the desert dust contribution to the total aerosol load. However, very few studies have ac- complished this task over a long period and from a multiyear perspective. To our knowledge, only the inventory of Toledano et al. (2007b) addressed the DD contribution to AOD between 2000 and 2005 at a Spanish south-western site (El Arenosillo). For $\mathrm{PM}_{x}$ data we have found various studies, such as the more recent publication by Salvador et al. (2013, 2014) and Pey et al. (2013a). Salvador et al. (2013) reported a DD inventory, and the corresponding contribution of DD is determined over the Madrid area over the period 2001-2011, which is extended to several stations covering the whole IP by Salvador et al. (2014). Pey et al. (2013a), with the same methodology as Salvador et al. (2013), analysed the period 2001-2011 for $\mathrm{PM}_{10}$ at different sites over the whole Mediterranean Basin. In these three studies, the method used for the evaluation of the DD contribution to $\mathrm{PM}_{x}$ is different to that for AOD. Therefore, the development of methodologies for the evaluation of DD contribution is an open area of research, for instance, to obtain the near real-time DD contribution value.

Within this framework, the main purpose of this study is to establish an inventory of DD episodes together with the evaluation of their contribution to the total aerosol load, using both $\mathrm{AOD}$ and $\mathrm{PM}_{x}$ data. This is the first time, to our knowledge, that DD events are identified by the simultaneous use of both columnar (AOD and $\alpha$ ) and surface $\left(\mathrm{PM}_{x}\right)$ aerosol observations. The methodology is applied over one of the cleanest atmospheric areas in southwestern Europe, the north-central area (Castilla y León region) of the Iberian Peninsula, for a long time period spanning more than 1 decade (2003-2014). Regarding the columnar aerosol data, the reliable measurements performed within the AErosol RObotic NETwork, AERONET (Holben et al., 1998), are used. For the study area, the only available aerosol long-term data set is recorded at the Palencia site $\left(41.9^{\circ} \mathrm{N}\right.$, $4.5^{\circ} \mathrm{W} ; 750 \mathrm{~m}$ a.s.l.). Regarding surface aerosols, we use the high-quality particulate-matter data recorded by the European Monitoring and Evaluation Programme (EMEP) network in the nearby Peñausende station $\left(41.28^{\circ} \mathrm{N}, 5.87^{\circ} \mathrm{W}\right.$; 985 ma.s.1.), with similar background conditions to Palencia. In this way, the use of these two worldwide extended and high-quality networks will ensure the feasibility of implementing the proposed method in other regions. The longterm inventory described hereafter has been employed to establish the main characteristics of the DD episodes in north-central Spain: their climatology, interannual behaviour, trends for the number of episodes and associated days, and occurrence under different synoptic scenarios. In addition, the evaluation of the DD contribution to the total mean values of AOD and $\mathrm{PM}_{x}$ is also addressed over the period investigated from a climatological and interannual perspective, which emphasizes the correlations between both quantities.

Section 2 describes the region of study and the datasets used. The methodology followed in the DD identification and in the evaluation of its contribution to aerosol load is presented in Sect. 3. In Sects. 4.1-4.3, the seasonal cycles 


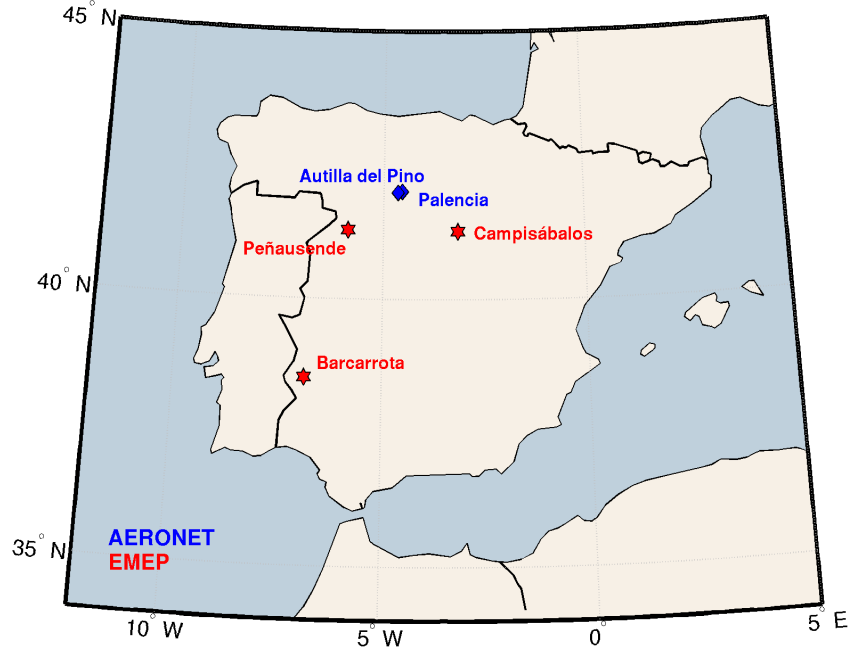

Figure 1. Location of the main sites used in this study belonging to AERONET (blue diamonds) and EMEP (red stars) networks.

and interannual evolution of DD events and dusty days and the DD contribution to AOD and $\mathrm{PM}_{x}$ are investigated. Section 4.4 provides an estimation of the uncertainty in this method and Sect. 4.5 describes the synoptic scenarios associated with the arrival of DD episodes in the north-central Iberian Peninsula. Finally, Sect. 5 summarizes the main findings obtained in this study.

\section{Sites of measurements and database}

\subsection{AERONET network and AOD and Ångström exponent database}

The main database for this study includes the instantaneous values of AOD obtained for $440 \mathrm{~nm}$ (henceforth AOD for clarity) and the Angström exponent ( $\alpha$ for the $440-870 \mathrm{~nm}$ range) measured at the Palencia site of the AERONETEUROPE network (see Fig. 1 and Table 1). The instrument used to obtain these data is a Cimel CE318 radiometer which measures under clear sky conditions and every 15 minutes. The raw measurements in all-sky conditions (level 1.0 of AERONET criteria), the cloud-screened data (level 1.5), and the high-quality processed data in level 2.0 are used in this study. Lower-quality levels help to reliably determine the duration of each DD episode, in particular, when the event includes cloudiness. Aerosol measurements have been available at the Palencia site since 2003, one of the longest series of aerosol optical measurements in the Iberian Peninsula (Mateos et al., 2014a). The number of available days for every year in this study can be seen in Table 1 . The standardization protocols of AERONET require pre- and postcalibration of the instruments after a field measuring period of 12 months, which helps to ensure the quality of the obtained data and associates an uncertainty for $\mathrm{AOD}_{440 \mathrm{~nm}}$ of \pm 0.01 and for the derived $\alpha$ parameter of about \pm 0.03 (see, e.g., Toledano et al., 2007a).

The Palencia site is placed in the autonomous region of Castilla y León in the north-central Iberian Peninsula, which is also known as the Castilian plateau, with an average altitude of $\sim 800 \mathrm{~m}$. This region is the third-least populated community in Spain due to its large area $\left(94193 \mathrm{~km}^{2}\right)$ and its low population (2543413 inhabitants registered in the census in 2012), with a population density just a bit higher than 27 inhabitants per square kilometre. Palencia is a small city (100 000 inhabitants) located in the north of Castilla y León but the measuring site is located on the outskirts, being surrounded by rural areas, removed from big urban and industrial centres. Hence, this area exhibits an exceptionally clean atmosphere, and aerosol observations are representative of the background conditions for the whole region. Therefore, desert dust intrusions can be observed since they significantly modify the background aerosol properties.

In order to fill the gaps in the Palencia AOD database, the site Autilla $\left(42.00^{\circ} \mathrm{N}, 4.60^{\circ} \mathrm{W} ; 873 \mathrm{~m}\right.$ a.s.l.) close to Palencia ( $7 \mathrm{~km}$ apart) has been used (for details see Bennouna et al., 2013). This site is used by GOA (Grupo de Optica Atmosférica) as the calibration platform for Cimel sun photometers within the AERONET-EUROPE infrastructure and also works as a routine measurement site. Under these considerations, the columnar aerosol data series used in this study is consistent and allows one to perform the inventory of DD events in this region.

\subsection{EMEP network and PM database}

Daily $\mathrm{PM}_{10}$ and $\mathrm{PM}_{2.5}$ measurements provided by the EMEP network constitute the second core database used to carry out this study (see Fig. 1 and Table 1). This network has the objective of regularly providing qualified scientific data to interested organizations in order to analyse and assess the transboundary transport and emission of pollutants (e.g. Aas et al., 2013). This is the objective of the LRTAP (Long-Range Transboundary Air Pollution) convention that establishes a framework for cooperative action for reducing the impact of air pollution. Using the $\mathrm{PM}_{10}$ and $\mathrm{PM}_{2.5}$ data, the particulate matter associated with coarse particles $\left(\mathrm{PM}_{2.5-10}\right)$ can be determined by taking the difference of these quantities $\left(\mathrm{PM}_{10}-\right.$ $\mathrm{PM}_{2.5}$ ).

$\mathrm{PM}_{10}$ and $\mathrm{PM}_{2.5}$ data belonging to the EMEP site of Peñausende have also been used for the detection of dusty days and for the evaluation of the DD contribution to the total $\mathrm{PM}_{x}$ levels. However, in order to better detect the DD episodes that arrive at our study area, two nearby stations (Campisábalos, $41.28^{\circ} \mathrm{N}, 3.14^{\circ} \mathrm{W}, 1360 \mathrm{~m}$ a.s.l., and Barcarrota, $38.48^{\circ} \mathrm{N}, 6.92^{\circ} \mathrm{W}, 393 \mathrm{~m}$ a.s.1.; see Fig. 1) are taken as complementary sites. All these three sites (Peñausende, Campisábalos, and Barcarrota) are placed in rural areas where background values are measured and the detection of Saharan desert dust intrusions is also possible. Among all 
Table 1. Annual sum of days with aerosol data of AERONET and EMEP databases ("all days") used in this study. Yearly number of dusty days in the DD inventory ("desert dust event days") identified by criteria of AOD, $\mathrm{PM}_{10}$, AOD, and PM 10 and other ancillary information. The relative coverage (percentage) is also given in parenthesis. See Sect. 3 for further details about the criteria used.

\begin{tabular}{lcccccccccccccc}
\hline & 2003 & 2004 & 2005 & 2006 & 2007 & 2008 & 2009 & 2010 & 2011 & 2012 & 2013 & 2014 & Total \\
\hline & & & & & & All days \\
\hline Sampling AOD & 156 & 265 & 295 & 190 & 271 & 280 & 256 & 244 & 269 & 252 & 220 & 249 & 2947 \\
$(\%)$ & $(42.8)$ & $(72.4)$ & $(80.8)$ & $(52.1)$ & $(74.2)$ & $(76.5)$ & $(70.1)$ & $(66.8)$ & $(73.7)$ & $(68.9)$ & $(63.3)$ & $(68.2)$ & $(67.2)$ \\
\hline Sampling PM 10 & 343 & 349 & 340 & 347 & 349 & 333 & 341 & 347 & 347 & 319 & 332 & 335 & 4082 \\
$(\%)$ & $(94.0)$ & $(95.4)$ & $(93.2)$ & $(95.1)$ & $(95.6)$ & $(91.0)$ & $(93.4)$ & $(95.1)$ & $(95.1)$ & $(87.2)$ & $(91.0)$ & $(91.8)$ & $(93.1)$ \\
\hline Coincident sampling & 149 & 256 & 279 & 183 & 259 & 255 & 243 & 238 & 256 & 219 & 200 & 234 & 2771 \\
$(\%)$ & $(40.8)$ & $(69.9)$ & $(76.4)$ & $(50.1)$ & $(71.0)$ & $(69.7)$ & $(66.6)$ & $(65.2)$ & $(70.1)$ & $(59.8)$ & $(57.5)$ & $(64.1)$ & $(63.2)$ \\
\hline
\end{tabular}

Desert dust event days

\begin{tabular}{|c|c|c|c|c|c|c|c|c|c|c|c|c|c|}
\hline Number of dusty days & 44 & 44 & 41 & 67 & 44 & 31 & 24 & 19 & 32 & 29 & 15 & 28 & 418 \\
\hline $\begin{array}{l}\text { Only AOD criterion } \\
(\%)\end{array}$ & $\begin{array}{c}5 \\
(11.4)\end{array}$ & $\begin{array}{c}8 \\
(18.2)\end{array}$ & $\begin{array}{c}9 \\
(22.0)\end{array}$ & $\begin{array}{c}6 \\
(9.0)\end{array}$ & $\begin{array}{c}14 \\
(31.8)\end{array}$ & $\begin{array}{c}4 \\
(12.9)\end{array}$ & $\begin{array}{c}4 \\
(16.7)\end{array}$ & $\begin{array}{c}5 \\
(26.3)\end{array}$ & $\begin{array}{c}9 \\
(28.1)\end{array}$ & $\begin{array}{c}12 \\
(41.4)\end{array}$ & $\begin{array}{c}2 \\
(13.3)\end{array}$ & $\begin{array}{c}2 \\
(7.1)\end{array}$ & $\begin{array}{c}80 \\
(19.1)\end{array}$ \\
\hline $\begin{array}{l}\text { Only } \mathrm{PM}_{10} \text { criterion } \\
(\%)\end{array}$ & $\begin{array}{c}19 \\
(43.2)\end{array}$ & $\begin{array}{c}3 \\
(6.8)\end{array}$ & $\begin{array}{c}11 \\
(26.8)\end{array}$ & $\begin{array}{c}37 \\
(55.2)\end{array}$ & $\begin{array}{c}6 \\
(13.6)\end{array}$ & $\begin{array}{c}2 \\
(6.5)\end{array}$ & $\begin{array}{c}7 \\
(29.2)\end{array}$ & $\begin{array}{c}2 \\
(10.5)\end{array}$ & $\begin{array}{c}0 \\
(0)\end{array}$ & $\begin{array}{c}1 \\
(3.4)\end{array}$ & $\begin{array}{c}8 \\
(53.3)\end{array}$ & $\begin{array}{c}18 \\
(64.3)\end{array}$ & $\begin{array}{c}114 \\
(27.3)\end{array}$ \\
\hline $\begin{array}{l}\text { AOD\&PM } 10 \text { criteria } \\
(\%)\end{array}$ & $\begin{array}{c}20 \\
(45.5)\end{array}$ & $\begin{array}{c}33 \\
(75.0)\end{array}$ & $\begin{array}{c}21 \\
(51.2)\end{array}$ & $\begin{array}{c}23 \\
(34.3)\end{array}$ & $\begin{array}{c}22 \\
(50.0)\end{array}$ & $\begin{array}{c}25 \\
(80.6)\end{array}$ & $\begin{array}{c}11 \\
(45.8)\end{array}$ & $\begin{array}{c}9 \\
(47.4)\end{array}$ & $\begin{array}{c}23 \\
(71.9)\end{array}$ & $\begin{array}{c}15 \\
(51.7)\end{array}$ & $\begin{array}{c}4 \\
(26.7)\end{array}$ & $\begin{array}{c}8 \\
(28.6)\end{array}$ & $\begin{array}{c}214 \\
(51.2)\end{array}$ \\
\hline $\begin{array}{l}\text { Other criteria } \\
(\%)\end{array}$ & $\begin{array}{c}0 \\
(0)\end{array}$ & $\begin{array}{c}0 \\
(0)\end{array}$ & $\begin{array}{c}0 \\
(0)\end{array}$ & $\begin{array}{c}1 \\
(1.5)\end{array}$ & $\begin{array}{c}2 \\
(4.5)\end{array}$ & $\begin{array}{c}0 \\
(0)\end{array}$ & $\begin{array}{c}2 \\
(8.3)\end{array}$ & $\begin{array}{c}3 \\
(15.8)\end{array}$ & $\begin{array}{c}0 \\
(0)\end{array}$ & $\begin{array}{c}1 \\
(3.4)\end{array}$ & $\begin{array}{c}1 \\
(6.7)\end{array}$ & $\begin{array}{c}0 \\
(0)\end{array}$ & $\begin{array}{c}10 \\
(2.4)\end{array}$ \\
\hline
\end{tabular}

Spanish EMEP sites, these two complementary sites (Campisábalos and Barcarrota) have not been randomly selected, since their geographical locations help us to have more information about the path followed by the intrusion before arriving in our study area. The direction of arrival can be established by measurements from the west (by the Peñausende site), south-west (by the Barcarrota site), and south-east (by the Campisábalos site).

The available time period for the $\mathrm{PM}_{x}$ data starts in 2001, but the same period (2003-2014) used in the $\mathrm{AOD}_{440 \mathrm{~nm}}$ is considered for the homogenization of the results presented in this study. It is important to emphasize here that in spite of the distance between the Peñausende and Palencia sites $(\sim 100 \mathrm{~km})$, the absence of any large landforms between them together with their atmospheric and background conditions make possible the joint discrimination and evaluation of these observations of AOD and $\mathrm{PM}_{x}$ for the detection of DD intrusions. Furthermore, an analysis of the air masses at Peñausende and Palencia sites (not shown here) has been carried out, corroborating that the geographical distance between them is negligible for the analysis of regional quantities such as AOD, water vapour, and the ozone column, among others.

The use of $\mathrm{AOD}_{440 \mathrm{~nm}}, \alpha, \mathrm{PM}_{10}$, and $\mathrm{PM}_{2.5}$ observations provides a comprehensive database to carry out an analysis of aerosol load and particle size, both at the surface and in the whole atmospheric column. Table 1 presents a detailed description of the number of days with available data every year for each database. Overall, $\mathrm{PM}_{x}$ presents a larger amount of days with data than AOD. Particularly, the year 2003 presents the lowest AOD sampling (42\% of 365 days) because of gaps just at the start of the sun photometer measurements.

\subsection{Ancillary information}

To carry out a more accurate evaluation and discrimination of days that constitute a desert dust intrusion, ancillary information is also considered. Air mass back trajectories arriving at Palencia at 12:00 UTC have been calculated with the HYSPLIT model (Hybrid Single-Particle Lagrangian Integrated Trajectory), version 4 (Draxler et al., 2014; Stein et al., 2015). Due to the fact that desert dust aerosols can be transported to altitude levels higher than the boundary layer, back trajectories have been calculated for three heights (500, 1500 , and $3000 \mathrm{~m}$ above ground level) and analysed 5 days back in time $(120 \mathrm{~h})$, using the model vertical velocity in the calculations. The meteorological database used as input for HYSPLIT is the Global Data Assimilation System (GDAS) GDAS1 dataset (e.g. Su et al., 2015). These three levels are commonly used in these studies to represent the air masses near the surface, in the boundary layer, and in the free troposphere, in order to follow the vertical transport of aerosols.

Information about cloudiness is obtained from MODIS (Moderate Resolution Imaging Radiometer) rapid response imagery products (https://earthdata.nasa.gov/ data/near-real-time-data/rapid-response). In addition, GIOVANNI (Geospatial Interactive Online Visual- 
ization ANd aNalysis Infrastructure) MODIS AOD aerosol maps (http://giovanni.gsfc.nasa.gov/giovanni/) and those provided by the AERONET website (http://aeronet.gsfc.nasa.gov/cgi-bin/bamgomas_interactive) are used to determine the extension and path followed by the mineral dust air masses for a DD identified event. The NAAPS Global Aerosol model (Navy Aerosol Analysis and Prediction System; available at http://www.nrlmry.navy.mil/aerosol/) is also used to test whether model forecasts also detect a given DD episode over the study area.

As shown in previous studies (Escudero et al., 2005; Toledano et al., 2007b) desert dust intrusions over Spain take place under certain synoptic scenarios (see Sect. 4.5 for further details). Through the Earth System Research Laboratory of NOAA (National Oceanic and Atmospheric Administration), the plots of the geopotential height at $700 \mathrm{hPa}$ and mean sea level pressure are obtained in order to evaluate the synoptic scenario associated with a given DD episode among the four possibilities (see Sect. 4.5) proposed by Escudero et al. (2005).

\section{Methodology}

\subsection{Detection of desert dust episodes}

This study is based on instantaneous $\mathrm{AOD}_{440 \mathrm{~nm}}$ and $\alpha$ values, as well as daily $\mathrm{PM}_{10}$ and $\mathrm{PM}_{2.5} / \mathrm{PM}_{10}$ ratio data. The method for the detection of desert dust (DD) intrusions is a manual inspection of the evolution of these four quantities together with the origin of the air masses at the three levels of altitude at 500, 1500, and $3000 \mathrm{~m}$ a.s.l. and the auxiliary material of AOD MODIS maps, aerosol models, and synoptic scenarios. The methodology for detection is similar to that applied in Toledano et al. (2007b) with the added information of $\mathrm{PM}_{x}$ data, and not much different from that used in other studies also based on a set of different observations (Escudero et al., 2005; Pace et al., 2006; Kalivitis et al., 2007; MAGRAMA, 2013). The difference between these methods lies on the weight given to each quantity and the way the information is analysed. For example in our case the AOD$\mathrm{PM}_{x}$ data are the primary information, but in other studies the primary variable is the origin of the air masses (Pace et al., 2006; Valenzuela et al., 2012a). Meteorological products and forecast aerosol models can also be used for this task (MAGRAMA, 2013). Although automatic methods can be applied in the DD identification, a visual inspection should be performed to corroborate each classification.

This study has been carried out as a year-by-year service to the "Consejería de Medio Ambiente" of the Autonomous Community of Castilla y León by means of two research programmes from 2006 to 2013 entitled "Discrimination, characterization and evaluation of desert dust outbreaks over 'Castilla y León' region”. These programmes aim to help im- plement the "Environmental Quality Improvement Policy" of the EU by the national and regional governments of Spain. The experience gained with this year-by-year identification provides the final DD inventory presented in this study.

Thresholds have been established to identify those conditions which stand above the clean background over the study area. Hence, the choice of these thresholds is based on the aerosol climatology of the site from our investigations (Bennouna et al., 2014; Mateos et al., 2015) and previous results (see, e.g., Querol et al., 2009, 2014). The mean values for the long-term period 2003-2014 are $0.13 \pm 0.09$ for $\mathrm{AOD}_{440 \mathrm{~nm}}$ and $10 \pm 9 \mu \mathrm{g} \mathrm{m}^{-3}$ for $\mathrm{PM}_{10}$. Hence, to detect the DD intrusions a visual inspection of the entire database is performed. When a day shows a group of a number of points of the instantaneous AOD $\geq 0.18$ and/or the daily $\mathrm{PM}_{10} \geq$ $13 \mu \mathrm{g} \mathrm{m}^{-3}$, that day is further investigated. The AOD threshold corresponds to the mean value plus half of the standard deviation, approximately; meanwhile that for $\mathrm{PM}_{10}$ is about the mean plus one third of the standard deviation. Hence, these thresholds must be taken as "warning flags" in the sense that these values alone do not define the classification as a dusty day. They also need the ancillary information given by the air mass backwards trajectories, satellite images, weather maps, and model forecasts to determine and corroborate the origin of aerosols and synoptic conditions. Therefore, with all this information, the human observer decides if a day must be included or not in the DD inventory.

In parallel to the above analysis, the evolution of the $\alpha$ quantity is also checked, allowing the identification of two different types of DD intrusions. Those days displaying $\alpha \leq$ 1.0 in most of the instantaneous columnar data are identified as the "purer" desert dust intrusions, and they are denoted by a D flag. Those days with $\alpha$ values in the interval $1.0 \leq \alpha \leq$ 1.5 (which have been classified as dusty days by their aerosol load and/or the ancillary information) present a mixture with other types (e.g. clean continental aerosols) and they are denoted by an MD (mixed desert) flag. The MD event days may either be a part of an intense event (generally of the D type) or form by themselves a low to moderate intensity event. Previous studies have also shown that DD intrusions into the Mediterranean Basin can present moderate AOD associated with large $\alpha$ values (e.g. Pace et al., 2006; Tafuro et al., 2006; Boselli et al., 2012). The limit of $\alpha \leq 1$ for identifying coarse particles has been established by previous studies in different worldwide areas (e.g. Eck et al., 1999, 2010; Dubovik et al., 2002; Meloni et al., 2007; Boselli et al., 2012), making this threshold suitable for our study area. It is important to emphasize here that the $\alpha$ parameter allows a more accurate identification of desert dust events. In particular, it allows the identification of those of low intensity, which have less of the characteristics identifying a desert origin (overall, the larger the AOD of a desert event, the lower the $\alpha$ ) because they are generally mixed with other aerosol types and are not accounted for in many DD studies (e.g. Gkikas et al., 2013). These DD events of low intensity are more difficult to detect 
because of the low signal of mineral dust aerosols, and hence it is more difficult to evaluate their contribution or impact on $\mathrm{AOD}$ and $\mathrm{PM}_{x}$ daily values. In fact, although the aerosol load threshold used in this study might seem very low, we must note again here that all these quantities are manually supervised by the expert observer who will take the final decision of the inclusion or not of a dusty day, bearing in mind all the available information given by these data and all the complementary material.

Another problem to be considered in the identification of a dusty day is when $\mathrm{AOD}$ and $\mathrm{PM}_{10}$ measurements show different information. For instance, AOD fingerprints seem to indicate a possible desert dust presence meanwhile $\mathrm{PM}_{10}$ does not. It must be taken into account that the $\mathrm{PM}_{10}$ quantity does not necessarily follow the same temporal behaviour as the AOD and possible time delays in $\mathrm{PM}_{10}$ concentration due to the fact that deposition processes can occur. Desert dust events can reach the IP at high-altitude layers (e.g. above 2000 m; Gkikas et al., 2015), and dry deposition can last various hours day ${ }^{-1}$. Assuming an average speed of deposition of around $0.6 \mathrm{~cm} \mathrm{~s}^{-1}$ (Zender et al., 2003), DD particles can remain in the troposphere for up to 2 days after an episode ends (Escudero et al., 2007). Hence, these possible time delays between columnar air masses and surface $\mathrm{PM}_{10}$ are very variable (e.g. Kalivitis et al., 2007; Pey et al., 2013a). Therefore, $\mathrm{AOD}$ and $\mathrm{PM}_{10}$ observations must be considered to be complementary information to detect mineral dust aerosols since with the evolution of both quantities it is easier to identify DD fingerprints.

It is worth mentioning that in the general detection of both intensity and duration of a particular event, DD causes an increase in the $\mathrm{AOD}_{440 \mathrm{~nm}}$ and $\mathrm{PM}_{10}$ values, which then surpass or just reach the corresponding threshold, together with a decrease in the $\alpha$ and $\mathrm{PM}_{2.5} / \mathrm{PM}_{10}$ values, giving rise to an increase in the mean size of the particle distribution. The duration of each intrusion can be established, since the low typical values, characteristic of the regional background, are recovered when the event finishes. The central or most intense days of each event are easy to detect due to the large increment of aerosol load with large particles ( $\alpha$ even close to zero) but low to moderate events are more difficult to detect. Although the events vary in their nature, the first and last days of a DD event show a low or moderate signature of mineral dust particles because of its mixture with other aerosol types (e.g. clean continental aerosol in our study area), with the exception of the strong DD events which generally have a notable impact on the aerosol load levels from the first day of the episode.

In the inspection of the instantaneous columnar dataset, non-reliable records are identified and removed due to their high spread in the data likely attributed to cloudy conditions. In the corroboration of some critical decisions made by the expert observer the ancillary information (see Sect. 2.3) constitutes a key point of the methodology. For instance, the verification of cloudy conditions can be supported by means of a comparison between AOD instantaneous data from different levels, 1.0 (all-sky conditions) and 1.5 (cloud-screened data), and the visualization of cloud systems in MODIS true-colour and cloud product images. If there are signs of cloud presence, instantaneous AOD data are carefully checked to discern between cloud-contaminated data and a DD intrusion.

Once aerosol load measurements for a given day indicate the likely classification as a dusty day, the air mass back trajectories (calculated as described in Sect. 2.3) are visualized to check if the origin of the path or the path followed crosses the north African region and/or its surroundings. Therefore, the air mass back-trajectory analysis and the geopotential maps (establishing a particular synoptic scenario, see Sects. 2.3 and 4.5) lead to the final decision with respect to a DD event day classification, even for those days showing cloudiness. Finally, to help in the understanding of the general situation regarding the geographical distribution of the aerosol plumes, AOD MODIS maps and NAAPS forecasts are also visualized for ensuring the final choice. The consistency of the information used provides a reliable identification of the DD event.

It is worth mentioning here that the final decision to include a day as D or MD is made by the human observer with all the available information at hand. Perhaps this methodology is not the most adequate to apply for a big area with a high number of sites and long-term databases, but it is necessary for developing methodologies, because it will allow the validation of other more automatic methods (e.g. those only based on threshold criteria), most of them using satellite observations (e.g. Gkikas et al., 2013, 2015).

\subsection{Evaluation of desert dust contribution to total AOD and total $\mathrm{PM}_{10}$ concentration}

Once the DD inventory is established, the evaluation of the DD contribution can be addressed on seasonal and annual scales. Following Toledano et al. (2007b), the contribution of the DD events to AOD can be obtained as the difference of the multi-annual monthly means considering all days and the corresponding value without including the desert dust cases. This procedure was also used for $\mathrm{PM}_{10}$ data in a 3-year evaluation of net DD contribution at several sites in the Mediterranean Basin (Querol et al., 2009). In this study, the annual cycle of the DD contribution to $\mathrm{AOD} / \mathrm{PM}_{x}$ is evaluated with this same methodology over the entire period 2003-2014, using the DD event days classified in the inventory. Furthermore, the relative DD contribution to AOD / $\mathrm{PM}_{x}$ can be obtained by dividing each one with respect to the corresponding total $\mathrm{AOD} / \mathrm{PM}_{x}$ value. Regarding the seasonal evaluations, the classification is as follows: winter (December-JanuaryFebruary), spring (March-April-May), summer (June-JulyAugust), and autumn (September-October-November). Analogously, the yearly AOD / $\mathrm{PM}_{x}$ means excluding dusty days are subtracted from the yearly AOD $/ \mathrm{PM}_{x}$ means for all days to obtain the DD contribution on an annual timescale. 
This method assumes that the entire daily aerosol load (both surface and columnar) is due to DD aerosols, with the contribution of regional background aerosols also included. Thus, suitable timescales for this kind of DD contribution calculation are the annual and multi-annual monthly means over 12 years of data. The evaluations for every single day or month can be addressed using other methods, for instance the determination of percentile 40 of the time series without dusty days to evaluate the background conditions that are subtracted from $\mathrm{PM}_{x}$ levels (Escudero et al., 2007). This method has been taken as the standard by the European Commission for the evaluation of DD contribution to aerosol load at the surface (Viana et al., 2014; MAGRAMA, 2013, 2015).

The methodology used in this study leads to lower uncertainty in the annual cycle evaluation since there is good data coverage for the multi-annual monthly sampling (12 years). However, in the evaluation of the year-by-year DD contribution to aerosol load, a given year can present low coverage leading to a higher uncertainty. The inclusion or not of an uncertain DD event (e.g. data contaminated with clouds where cloud optical depth is assigned to aerosol AOD) can substantially modify the corresponding yearly mean as has been shown in Bennouna et al. (2014). This source of uncertainty must be considered in the temporal-trend evaluation. It is not easy to establish an adequate methodology to evaluate the DD aerosol contribution to aerosol load (Viana et al., 2010) and much less its corresponding associated error. A further investigation is necessary on this subject. A discussion about the uncertainty of our approaches in the DD identification and in the evaluation of DD contribution to aerosol load can be found in Sect. 4.4.

\section{Results and discussion}

\subsection{Evaluation of the number of episodes and days: annual cycle and year-to-year variability}

\subsubsection{Evaluation of the number of episodes and dusty days}

The inventory of desert dust intrusions includes the following: information on each episode and its associated days; the daily mean $\mathrm{AOD}, \alpha, \mathrm{PM}_{10}$, and $\mathrm{PM}_{2.5}$; and cloudiness, synoptic scenarios, and air mass origin at three altitude levels (500, 1500, and $3000 \mathrm{~m}$ a.s.1.). Tables 1 and 2 show the information used to classify DD events and the main statistics for this inventory, respectively.

The $\mathrm{PM}_{10}$ sampling presents the best coverage of the measuring time period with $93.1 \%$ of the days, AOD is available $67.2 \%$ of the time, and the coincident sampling is available $63.2 \%$ of the time. As can be deduced from Table 1, the majority $(51.2 \%)$ of the DD event days composing the inventory are noticeable in both AOD and $\mathrm{PM}_{10}$ datasets. However, $46.4 \%$ of the total detected days are over the required

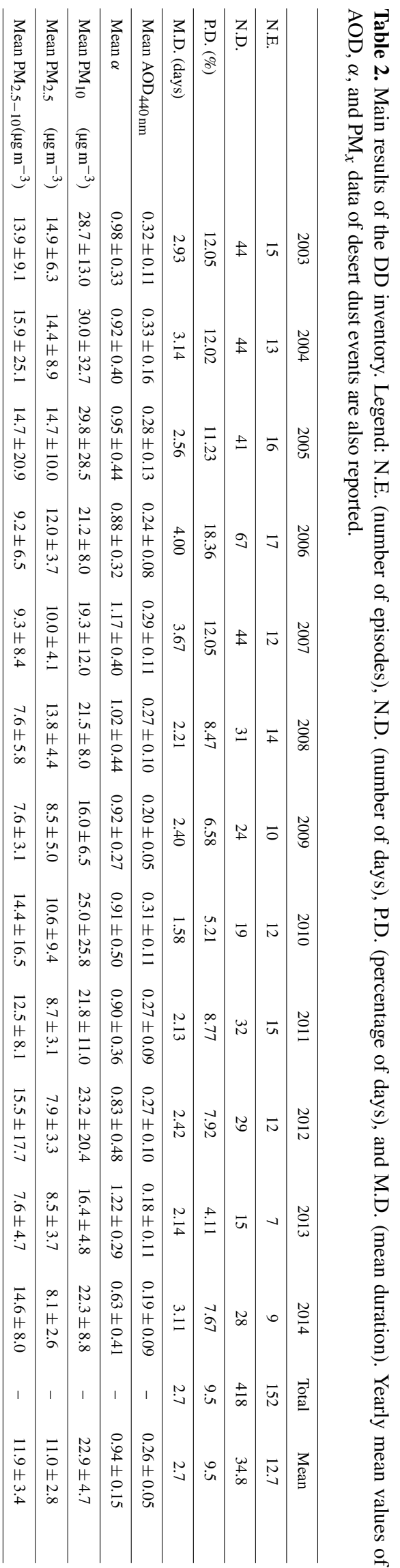

www.atmos-chem-phys.net/16/8227/2016/ 
thresholds only in one quantity (AOD or $\mathrm{PM}_{10}$ ). This is the advantage of the proposed inventory because DD outbreaks are identified with two complementary quantities about the aerosol load. The reasons behind this $46.4 \%$ (19.1\% only with AOD and $27.3 \%$ only with $\mathrm{PM}_{10}$ ) are due to time delays between columnar and surface levels related to deposition phenomena and also are due to the lack of AOD or $\mathrm{PM}_{10}$ measurements. Therefore, if the inventory is addressed by only one quantity, a large number of dusty days can be lost in their identification. Finally, a smaller number of cases $(2.4 \%)$ are identified as dusty days using the ancillary information when $\mathrm{AOD}$ and $\mathrm{PM}_{10}$ data are not available.

The smaller amount of available data in the AOD time series (see Table 1), in comparison with $\mathrm{PM}_{10}$, is not a major handicap in DD detection. There are several years (2004, 2007, 2008, 2010, 2011, and 2012) with more DD days detected only by AOD than only by $\mathrm{PM}_{10}$, in spite of the smaller AOD sampling (between 53 and 103 days less per year). However, years 2003 and 2006, which present less than 200 daily AOD data, require the use of $\mathrm{PM}_{10}$ to better identify DD intrusions.

As reported in Table 2, during 2003-2014, a total number of 152 episodes has been identified, composed of 418 days. Among them, 242 days have been classified as days with desert aerosols (D) and 176 days with mixed aerosols (MD). Overall, this means 13 episodes and 35 days per year with desert dust intrusion, representing $9.5 \%$ of the days each year. The duration of DD episodes is very variable, ranging from 1 to 13 days, but a value of 2.7 days is obtained as the mean episode duration. Due to the high variability in the intensity of these intrusions it is difficult to distinguish when an event has ended or its intensity has simply fallen below our threshold. During summer, the recirculation of air masses in the IP is very frequent and the DD episodes are subject to large intensity variations. We have considered separate DD episodes when there is, at least, 1 day that does not meet the DD requirements between two DD episodes.

Our percentage of dusty days of $9.5 \%$ is lower than that reported by Salvador et al. (2013), which is around $18 \%$ (18 episodes and 65 days per year). Salvador et al. (2013) analysed DD intrusions over the central Iberian Peninsula (Madrid area) between 2001 and 2008. This large difference between two nearby areas (separated by $\sim 200 \mathrm{~km}$ ) can be explained by the different time periods considered and the existence between these areas of a high mountain range (Sistema Central), with peaks up to $2400 \mathrm{~m}$ a.s.l. For the northeastern area of the Iberian Peninsula, Escudero et al. (2005) reported $15 \%$ of DD intrusions (16 episodes and 54 days per year) in the period 1996-2002, and Pey et al. (2013a) obtained $17-18 \%$ between 2001 and 2011.

\subsubsection{Annual cycle of the number of episodes and days}

The annual cycles of the number of episodes and number of days with DD conditions are presented in Fig. 2. In gen-
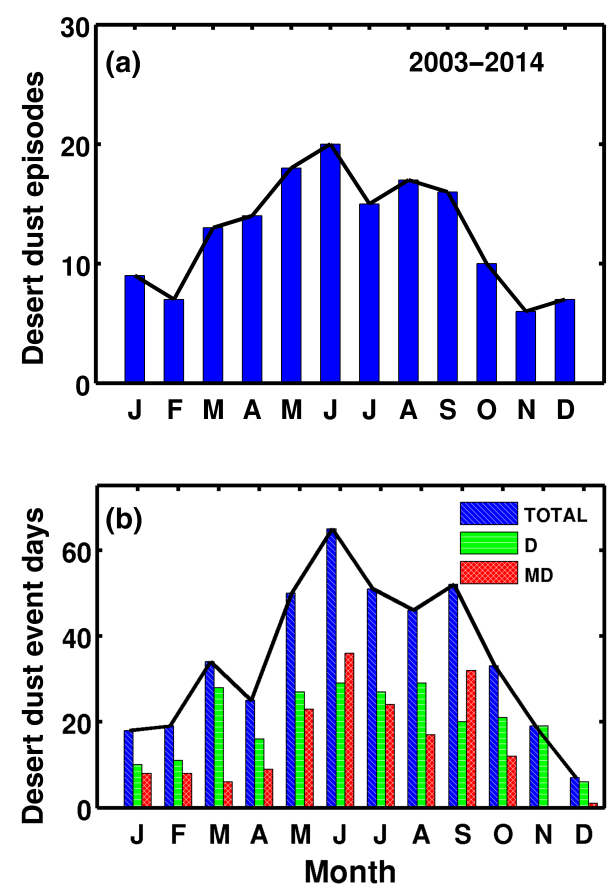

Figure 2. Annual cycle of (a) total number of episodes per month for total DD intrusions; (b) total (blue bars) number of days per month for total DD intrusions and for desert (D, green bars) and mixed desert (MD, red bars) categories in 2003-2014. Mean values per month can be derived by dividing by 12 .

eral, the seasonal pattern along the year followed by the number of episodes (Fig. 2a) and dusty days (Fig. 2b) is similar, with a significant increase in the DD occurrence in March (13 events and 34 dusty days), a weak fall of DD event days in April (14 events and 25 dusty days), a notable increment between May and September (around 17 events and 53 dusty days per month), and a progressive decline to the minima in November and December. The number of episodes and event days peaks in June (20 events and 65 dusty days). A noteworthy feature of this figure is the local minimum in the number of DD episodes in July (15 episodes in 2003-2014) which is shifted to August in the number of DD event days (46 dusty days in 2003-2014). Figure $2 \mathrm{~b}$ is similar in shape to that reported by Salvador et al. (2013) with the exception of September, and it is also similar to that of Escudero et al. (2005) with the exception of October. Concerning the two types of DD conditions distinguished in our inventory, the D type controls the annual cycle in the March maximum and April minimum, while the MD type controls the evolution between August and October.

Some features mentioned above regarding the seasonal behaviour of DD events for the north-central Spanish region are also observed for other areas of the IP. For instance, the March maximum and April minimum are common features in south-western (Toledano et al., 2007b; Obregón et al., 2012), north-eastern (Escudero et al., 2005; Papayannis et al., 

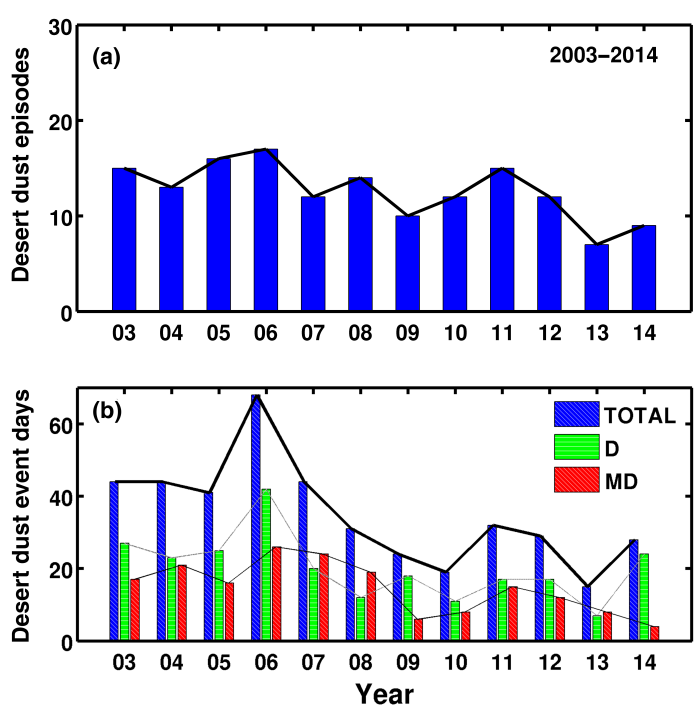

Figure 3. Interannual variability of (a) total number of episodes; (b) total (blue bars) number of days for the desert dust (DD) intrusions and for desert (D, green bars) and mixed desert (MD, red bars) categories.

2008), and central (Salvador et al., 2013) Spain. In spite of the different measuring instruments (sun photometer, lidar, or particulate-mass concentration), time periods, and methodologies employed in the DD event identification, its impact over (almost) all of the Iberian Peninsula follows the same pattern with the two maxima - one in late winter/early spring (March) and the other in summer - and the accentuated minimum of winter. Several minor discrepancies are found for the rest of the year; for example, the maximum number of DD event days during the summer months with a local minimum (in July) between them seems to be a characteristic of the annual cycles of the south-western (Toledano et al., 2007b) and north-central areas. Conversely, the eastern region presents a local maximum in October (Escudero et al., 2005; Pey et al., 2013a) which is not seen in our study region. These results confirm that different areas have different aerosol properties in the IP (Mateos et al., 2015). The larger occurrence of dusty days in summer and in certain spring and fall months is also observed in other Mediterranean areas using lidar networks to identify the occurrence of DD outbreaks (e.g. Mona et al., 2006; Papayannis et al., 2008).

\subsubsection{Interannual variability and trends of the number of episodes and days with DD}

The year-to-year variability for the number of both the episodes and days is reported in Table 2 and illustrated in Fig. 3. A large interannual variability is observed, which is more accentuated for the number of DD event days (Fig. 3b) with an apparent decreasing trend during the analysed period. A large number of dusty days is reported during the first 5 years (2003-2007), the maximum being in 2006 (67 days).
After 2007 there is a decline in DD event days up to 19 days in 2010, and a small upturn is observed in 2011, 2012, and 2014, with a sharp reduction in 2013. The lowest occurrence of DD events was in 2013 with only seven episodes and 15 dusty days that year $(4.11 \%)$. By contrast, the largest number of events took place in 2016 with 17 episodes composed of 67 days of dust intrusion (18.4\%). Nevertheless, the number of episodes and the number of days are not directly linked. For instance, 12 episodes are observed in both 2007 and 2010 but the former registered 44 days of intrusion, whereas the latter registered just 19 days. Furthermore, even though 2006 is the year with the highest occurrence of dusty days, it is not linked with the most intense events. Both $\mathrm{AOD}_{440 \mathrm{~nm}}$ and $\mathrm{PM}_{10}$ means (for DD days) are lower in 2006 than for previous years, in which a smaller occurrence of DD conditions is observed. The minimum load during DD days is registered in 2013 for the $\mathrm{AOD}_{440 \mathrm{~nm}}(0.18)$ and in 2009 for the $\mathrm{PM}_{10}$ $\left(16 \mu \mathrm{g} \mathrm{m}^{-3}\right)$, while the maximum occurred in $2004(0.33$ for AOD and $30 \mu \mathrm{g} \mathrm{m}^{-3}$ for $\left.\mathrm{PM}_{10}\right)$. Concerning the two classifications of DD event days (D and MD types), the years 2003, 2006, 2009, 2012, and 2014 are governed by the purer D type intrusions.

To quantify the decreasing trends in the number of episodes and associated days, the Theil-Sen estimator and Mann-Kendall test for significance have been used. The trends for the number of DD episodes and days are reported in Table 3 for the yearly values. A statistically significant trend at the $95 \%$ significance level presents a $p$ value below 0.05 (e.g. Sanchez-Lorenzo et al., 2013). The total number of dusty days has decreased by 2.7 days per year ( $p$ value of 0.02 ) between 2003 and 2014. This change, however, does not cause a significant trend in the number of episodes, which presents a decrease of 0.67 episodes per year with a $p$ value around 0.03 ( $\sim 97 \%$ of significance level). These figures corroborate a significant decrease in the DD events seen in the north-central area of the Iberian Peninsula over the past decade. This result is in line with the findings obtained by Gkikas et al. (2013) for the whole Mediterranean Basin using MODIS data between 2000 and 2007 and considering only very intense DD events selected by a high AOD threshold.

\subsection{Desert dust contribution to total AOD: seasonal cycle, interannual variability, and trends}

\subsubsection{Annual seasonal cycle}

Figure 4 and Table 4 show the annual cycle of the DD contribution (small red bars in the figure) together with the multiannual monthly means considering all days and only days without DD aerosols (the difference between these two values gives the DD contribution). Overall, the mean DD contribution to AOD is 0.015 or $11.5 \%$ in $2003-2014$.

The total AOD annual cycle representing the climatology follows the well-known pattern previously reported and ex- 
Table 3. Temporal trends (Theil-Sen estimator), $p$ value, and confidence interval ([i1, i2]) given by the quantities considered for all days and for the contribution of DD. For the DD inventory the number of episodes and DD event days is also included. Negative trend means a decrease in the quantity analysed.

\begin{tabular}{|c|c|c|c|c|c|c|c|}
\hline & Quantity & Trend & $p$ value & i1 & i2 & Trend units & $\begin{array}{r}\text { Trend } \\
(\% \text { per year) }\end{array}$ \\
\hline \multirow{4}{*}{ All days } & AOD & -0.006 & $<0.01$ & -0.009 & -0.003 & AOD units per year & -4.6 \\
\hline & $\mathrm{PM}_{10}$ & -0.46 & $<0.01$ & -0.66 & -0.30 & $\mu \mathrm{g} \mathrm{m}^{-3}$ per year & -4.5 \\
\hline & $\mathrm{PM}_{2.5}$ & -0.38 & $<0.01$ & -0.49 & -0.30 & $\mu \mathrm{g} \mathrm{m}^{-3}$ per year & -6.3 \\
\hline & $\mathrm{PM}_{2.5-10}$ & -0.07 & 0.19 & -0.19 & 0.07 & $\mu \mathrm{g} \mathrm{m}^{-3}$ per year & -1.6 \\
\hline \multirow{6}{*}{ DD inventory } & Number of episodes & -0.67 & 0.03 & -1.00 & 0.00 & N.E. per year & -5.2 \\
\hline & Number of DD event days & -2.7 & 0.02 & -4.2 & -1.30 & N.D. per year & -8.0 \\
\hline & DD contribution to AOD & -0.0019 & 0.016 & -0.003 & -0.000 & AOD units per year & -11.2 \\
\hline & DD contribution to $\mathrm{PM}_{10}$ & -0.14 & 0.06 & -0.26 & 0.01 & $\mu \mathrm{g} \mathrm{m}^{-3}$ per year & -10.1 \\
\hline & DD contribution to $\mathrm{PM}_{2.5}$ & -0.079 & $<0.01$ & -0.12 & -0.04 & $\mu \mathrm{g} \mathrm{m}^{-3}$ per year & -13.7 \\
\hline & DD contribution to $\mathrm{PM}_{2.5-10}$ & -0.085 & 0.06 & -0.16 & 0.00 & $\mu \mathrm{g} \mathrm{m}^{-3}$ per year & -10.0 \\
\hline
\end{tabular}

Table 4. Monthly mean contribution of DD to total AOD and $\mathrm{PM}_{x}$, in absolute ("abs.", AOD units and $\mu \mathrm{g} \mathrm{m}^{-3}$ ) and relative ("rel.", \%) values during the 2003-2013 period.

\begin{tabular}{llcccccccccccccc}
\hline & & Jan & Feb & Mar & Apr & May & Jun & Jul & Aug & Sep & Oct & Nov & Dec & Total \\
\hline \multirow{2}{*}{ AOD $_{440 \mathrm{~nm}}$} & abs. & 0.006 & 0.011 & 0.018 & 0.014 & 0.014 & 0.027 & 0.018 & 0.026 & 0.023 & 0.014 & 0.008 & 0.004 & 0.015 \\
& rel. & 6.05 & 9.94 & 13.38 & 9.37 & 9.86 & 17.07 & 12.07 & 17.42 & 15.66 & 12.37 & 9.55 & 5.40 & 11.51 \\
\hline $\mathrm{PM}_{10}$ & abs. & 0.51 & 0.58 & 2.23 & 0.81 & 0.96 & 2.28 & 2.35 & 2.38 & 1.16 & 1.37 & 0.83 & 0.23 & 1.31 \\
& rel. & 7.70 & 6.73 & 20.13 & 9.78 & 8.54 & 17.69 & 16.51 & 16.13 & 9.61 & 13.57 & 11.57 & 3.64 & 11.80 \\
\hline $\mathrm{PM}_{2.5}$ & abs. & 0.36 & 0.43 & 0.66 & 0.28 & 0.33 & 0.88 & 1.12 & 1.12 & 0.58 & 0.50 & 0.28 & 0.08 & 0.55 \\
& rel. & 7.85 & 7.16 & 10.50 & 5.60 & 5.00 & 11.99 & 13.64 & 13.40 & 8.33 & 9.71 & 7.26 & 1.88 & 8.53 \\
\hline $\mathrm{PM}_{2.5-10}$ & abs. & 0.20 & 0.17 & 1.67 & 0.47 & 0.69 & 1.40 & 1.25 & 1.33 & 0.58 & 0.93 & 0.56 & 0.17 & 0.79 \\
& rel. & 8.18 & 5.55 & 32.84 & 13.89 & 14.28 & 24.76 & 20.59 & 20.90 & 11.26 & 18.50 & 16.34 & 6.57 & 16.14 \\
\hline
\end{tabular}

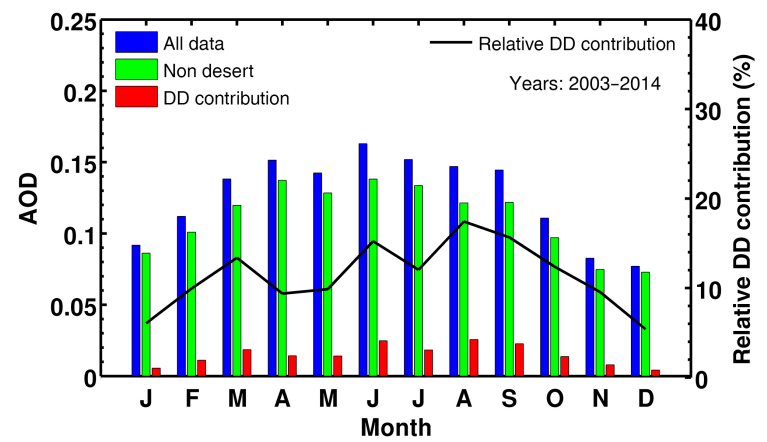

Figure 4. Annual cycle for DD contribution to the total monthly AOD means in absolute (red bar) and relative values (black line) in 2003-2014. Blue bars (also indicated as all data) represent the annual cycle of total AOD and green bars the corresponding values without including the days of desert dust (indicated as non desert).

plained for the Palencia site (see, e.g., Bennouna et al., 2013; Mateos et al., 2014a). To summarize: the increasing values from January to June (just when the maximum is found), with a slight reduction in May and a decreasing trend to the end of the year, almost provide a well-defined bell shape. As for the climatology with the DD episodes excluded, it preserves the bell pattern found before for the general case, except for some minor discrepancies. For instance, the change between May and June is not noticeable for the curve with the DD excluded, in contrast with the larger increment observed for the general case.

However, the seasonal pattern followed by the DD contribution displays two maxima: the first one in March (late winter/early spring) with 0.018 or $13.4 \%$ and the strongest one occurring in the summer period (June and August) with $\sim 0.027$ or $\sim 17 \%$. Together with these maxima, there are two local minima: in April-May (around 0.014 or $9.5 \%$ ) and in July (0.018 or $12 \%)$. After August, a progressive decline in the DD contribution is observed with the minimum in winter (December and January show similar values about 0.004 or $5.4 \%$ ). It is worth mentioning here the different characters of the two local minima occurring in April-May and July. The former generally occurs in the IP (linked to the precipitation cycle), while the latter is more typical of the central and south-western areas of Spain. For instance, the July min- 


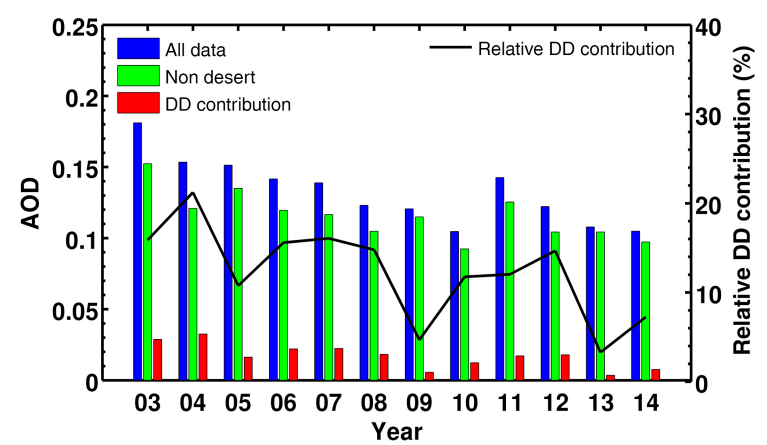

Figure 5. Interannual variability of DD contribution to the total yearly AOD in absolute (red bar) and relative values (black line). Blue bars (also indicated as all data) represent the mean yearly AOD value and green bars the corresponding values without including the days of desert dust (also indicated as non desert).

imum seems to be related to the arrival of drier air masses in the low troposphere as it is observed in the precipitable water vapour cycle (Ortiz de Galisteo et al., 2013).

The annual cycle of the DD contribution to the Palencia site (representing north-central Spain) presents a similar shape to that obtained in the El Arenosillo site (southwestern area) by Toledano et al. (2007b) for an inventory of 6 years, from 2000 to 2005 . This is an important result in two aspects: one related to the shape of the annual cycle or seasonal behaviour and the other one related to the different contribution of north and south areas of the IP. In relation to the geographical gradient of the African dust contribution, a quantitative difference is observed between these two areas. The total AOD signal is clearly impacted by DD events in the southern Iberian coast (with relative contributions being over $30 \%$ ), while in the north-central region the DD influence is weaker; thus, a south-north-decreasing gradient over the IP is observed regarding the DD contribution to AOD values. This behaviour is well known in the IP from earlier aerosol studies based on $\mathrm{PM}_{x}$ data (Querol et al., 2009; Pey et al., 2013a; Salvador et al., 2013, 2014), but this is the first time this is confirmed by an inventory of AOD data.

\subsubsection{Interannual variability and trends}

With respect to the interannual change in the DD contribution to AOD, Fig. 5 and Table 5 show its annual values between 2003 and 2014 (using the methodology explained in Sect. 3.2). In a quick-look analysis, both total AOD and DD contributions have a significant year-to-year variability with a decreasing trend during the period studied. The maximum DD contribution with a value of 0.033 or $21.2 \%$ took place in 2004 and also showed a maximum in the total AOD around 0.15 (the mean value of 2003 is clearly affected by the low sampling: $42.7 \%$, compared to the $72.4 \%$ in 2004). The year 2013 presents the absolute minimum of the DD contribution to AOD with 0.004 or $\sim 4 \%$, with a low contribution in 2009 too $(0.006$ or $\sim 5 \%)$. There is a weak evolution of the DD contribution until 2008, although 2005 presents a marked local minimum (DD contribution to AOD around 0.016 or $11 \%)$. There are years with simultaneous decreases (2008, $2009,2013)$ or increases $(2011,2014)$ in both total AOD and its DD contribution, but in other years they present the opposite behaviour (2005 and 2006). The solid line in Fig. 5 illustrating the evolution of the relative DD contribution to AOD highlights the minima of 2013, 2009, and 2005 and the maxima of 2004 and 2012. The high interannual variability can be explained by the typical variability of the different African source areas and associated emission processes together with the atmospheric conditions and transport patterns of DD aerosols that can reach the Iberian Peninsula (Prospero et al. 2002; Kaufman et al., 2005; Escudero et al., 2006; Knippertz and Todd, 2012; Salvador et al., 2014).

The temporal trends in total AOD and in the DD contribution to AOD are also evaluated and shown in Table 3 . The decrease in the total AOD in the Palencia site in 2003-2014 is 0.006 AOD units per year (with a $p$ value $<0.01$ ) or $4.6 \%$ per year, which is in line with previous findings for the same site by Bennouna et al. (2014) and Mateos et al. (2014b) for shorter (4 and 3 years, respectively) periods. With respect to the DD contribution to AOD, a decrease of 0.0019 AOD units per year $(p$ value $=0.02$ ) or $11.2 \%$ per year is calculated. Therefore, this rate represents $30 \%$ of the total AOD decreasing trend. Hence, the natural decrease in DD aerosols has notably affected AOD levels over the north-central Iberian Peninsula during the study period.

\subsection{Desert dust contribution to $\mathrm{PM}_{\boldsymbol{x}}$ levels: annual cycle, interannual variability, and trends}

\subsubsection{Annual seasonal cycle}

In the same way as for AOD, the contribution of desert dust events to mean values of $\mathrm{PM}_{10}, \mathrm{PM}_{2.5}$, and $\mathrm{PM}_{2.5-10}$ have also been calculated. The annual cycle and the interannual evolution of these three quantities and the corresponding DD contributions are reported in Tables 4 and 5 and also illustrated by Figs. 6 and 7, respectively.

The DD contribution to the total $\mathrm{PM}_{10}, \mathrm{PM}_{2.5}$, and $\mathrm{PM}_{2.5-10}$ is not usually evaluated at the same time. To our knowledge, this is the first time that fine- and coarse-mode contributions are evaluated in a long-term desert dust inventory of this type. Furthermore, the temporal trends for the interannual DD contributions are also discussed. It is worth mentioning here that as $\mathrm{PM}_{10}$ and $\mathrm{PM}_{2.5}$ are obtained from independent filters (see Sect. 2.2) while $\mathrm{PM}_{2.5-10}$ is only available with simultaneous $\mathrm{PM}_{x}$ data, the amount of data used in the evaluation of DD contribution for each quantity differs slightly.

According to Table 4, the mean DD contributions to $\mathrm{PM}_{x}$ during the study period are $1.3 \mu \mathrm{g} \mathrm{m}^{-3}$ (12\%) for $\mathrm{PM}_{10}, 0.6 \mu \mathrm{g} \mathrm{m}^{-3}(9 \%)$ for $\mathrm{PM}_{2.5}$, and $0.8 \mu \mathrm{g} \mathrm{m}^{-3}(16 \%)$ 
Table 5. Mean annual contribution of DD to total AOD and $\mathrm{PM}_{x}$ in absolute ("abs.", AOD units, and $\mu \mathrm{g} \mathrm{m}^{-3}$, respectively) and relative ("rel.", \%) values during the 2003-2013 period.

\begin{tabular}{llcccccccccccc}
\hline & & 2003 & 2004 & 2005 & 2006 & 2007 & 2008 & 2009 & 2010 & 2011 & 2012 & 2013 & 2014 \\
\hline \multirow{2}{*}{$\mathrm{AOD}_{440 \mathrm{~nm}}$} & abs. & 0.029 & 0.033 & 0.016 & 0.022 & 0.022 & 0.018 & 0.006 & 0.012 & 0.017 & 0.018 & 0.004 & 0.008 \\
& rel. & 15.87 & 21.22 & 10.76 & 15.59 & 16.06 & 14.78 & 4.68 & 11.75 & 12.03 & 14.67 & 3.76 & 7.25 \\
\hline $\mathrm{PM}_{10}$ & abs. & 2.29 & 2.35 & 2.07 & 2.39 & 1.18 & 1.08 & 0.50 & 0.94 & 1.11 & 1.14 & 0.39 & 1.25 \\
& rel. & 18.12 & 17.80 & 16.10 & 21.49 & 11.02 & 11.04 & 5.59 & 10.81 & 10.92 & 12.36 & 4.87 & 14.54 \\
\hline $\mathrm{PM}_{2.5}$ & abs. & 1.04 & 0.87 & 0.92 & 1.23 & 0.52 & 0.68 & 0.25 & 0.34 & 0.31 & 0.31 & 0.16 & 0.30 \\
& rel. & 13.07 & 10.27 & 11.95 & 17.79 & 8.10 & 10.36 & 4.76 & 6.92 & 5.99 & 6.88 & 3.52 & 6.55 \\
\hline $\mathrm{PM}_{2.5-10}$ & abs. & 1.38 & 1.61 & 1.21 & 1.21 & 0.73 & 0.42 & 0.27 & 0.65 & 0.71 & 0.91 & 0.18 & 1.01 \\
& rel. & 27.00 & 30.99 & 22.91 & 26.97 & 15.85 & 12.52 & 6.72 & 15.34 & 14.42 & 18.31 & 4.88 & 22.57 \\
\hline
\end{tabular}
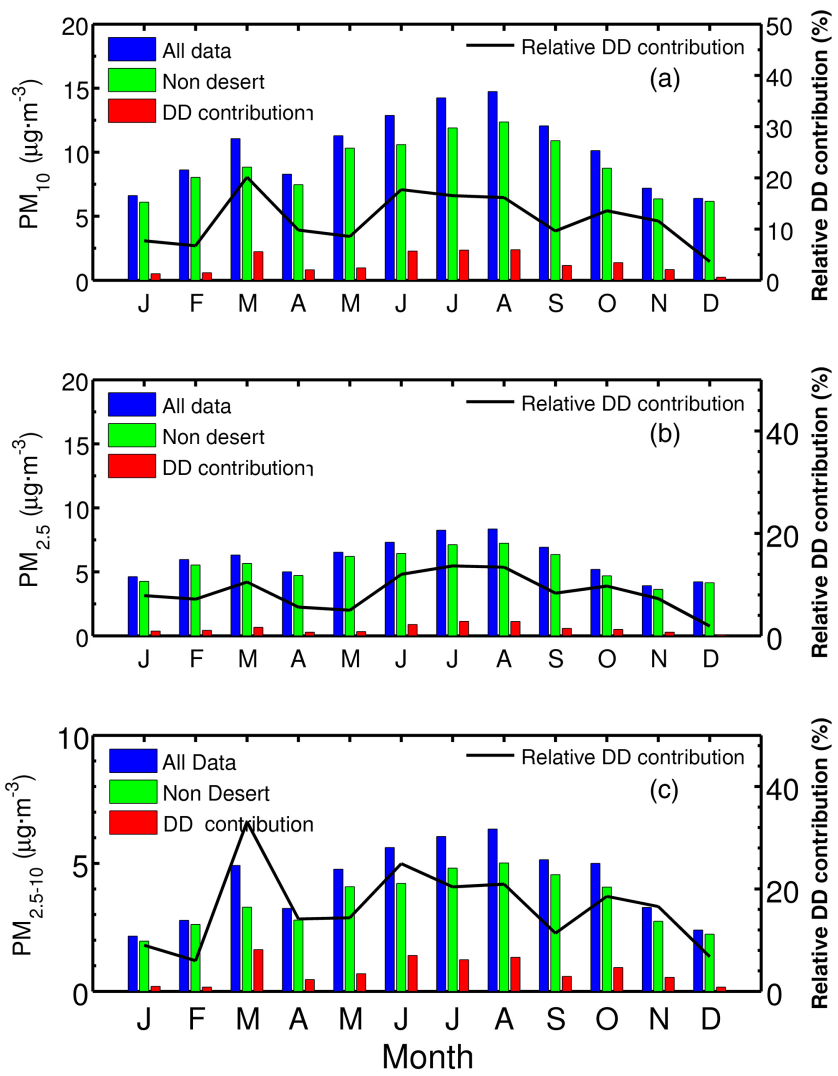

Figure 6. Annual cycle for DD contribution to the total monthly $\mathrm{PM}_{10}(\mathbf{a}), \mathrm{PM}_{2.5}$ (b), and $\mathrm{PM}_{2.5-10}$ (c) means in absolute (red bar) and relative values (black line) in 2003-2014. Blue bars represent the annual cycle of total $\mathrm{PM}_{10}(\mathbf{a}), \mathrm{PM}_{2.5}$ (b), and $\mathrm{PM}_{2.5-10}$ (c) and green bars the corresponding values without including the days of desert dust.

for $\mathrm{PM}_{2.5-10}$. Our findings during 2003-2014 are in line with those given by Querol et al. (2009): $2 \mu \mathrm{g} \mathrm{m}^{-3}$ for a 3 year period (2004-2006) of $\mathrm{PM}_{10}$ data at the Peñausende site. A decreasing south to north gradient of African dust contribution to $\mathrm{PM}_{10}$ (e.g. Querol et al., 2009; Pey et al., 2013a) is found for the north-central area of the IP. In particular, $\mathrm{PM}_{10}$ is similar to the averages in the north-eastern area $\left(<2 \mu \mathrm{g} \mathrm{m}^{-3}\right)$ and smaller than the values obtained at southern sites (up to 5$6 \mu \mathrm{g} \mathrm{m}^{-3}$ ). Our relative contribution is in line with the lowest values of the ranges reported by Salvador et al. (2013) using a chemical speciation analysis at three different sites near Madrid.

The total $\mathrm{PM}_{10}$ annual cycle (see Fig. 6) is well known in the north-central area of the Iberian Peninsula (see, e.g., Bennouna et al., 2014; Mateos et al., 2015); There are two maxima: a major one in summer and a secondary one in early spring (considering our seasonal classification with March as part of the spring). There is also a winter minimum and another minimum in April. This general behaviour for the entire dataset is also followed if the DD events are excluded. The evolution of these two latter curves is also followed by the DD contribution to $\mathrm{PM}_{10}$. The largest DD contribution is observed in March $\left(2.2 \mu \mathrm{g} \mathrm{m}^{-3}\right.$ or $\left.20 \%\right)$ and in the summer months of June to August $\left(\sim 2.3 \mu \mathrm{g} \mathrm{m}^{-3}\right.$ or $\left.\sim 17 \%\right)$. The months of April and May $\left(\sim 0.9 \mu \mathrm{g} \mathrm{m}^{-3}\right.$ or $\left.\sim 9 \%\right)$ display a notable decrease with respect to March. After summer, there is a sharp fall in September $\left(1.2 \mathrm{~g} \mathrm{~m} \mathrm{~m}^{-3}\right.$ or $\left.10 \%\right)$ producing a local minimum and beyond October a progressive decline leading to the weakest effect $(<8 \%)$ of the African intrusions during winter months (DJF). The maximum relative DD contribution to $\mathrm{PM}_{10}$ can reach $20 \%$, which is within the range (10-50\%) observed by Pey et al. (2013a) for the eastern Spanish coast. Comparing the seasonal cycles of DD contribution to $\mathrm{PM}_{10}$ in the latter area with respect to north-central Iberian Peninsula, some common features appear (March maximum, April-May decrease, summer increase, and September drop) but the maximum in October seen on the Mediterranean coast does not happen in the north-central area.

Even though both AOD and $\mathrm{PM}_{10}$ express the aerosol load, these quantities present noticeable differences. To facilitate the comparison of the results shown above, Fig. S1 (Supplement) shows the annual cycles of $\mathrm{AOD}$ and $\mathrm{PM}_{10}$ total means and their DD contributions together. The annual cycle of the 

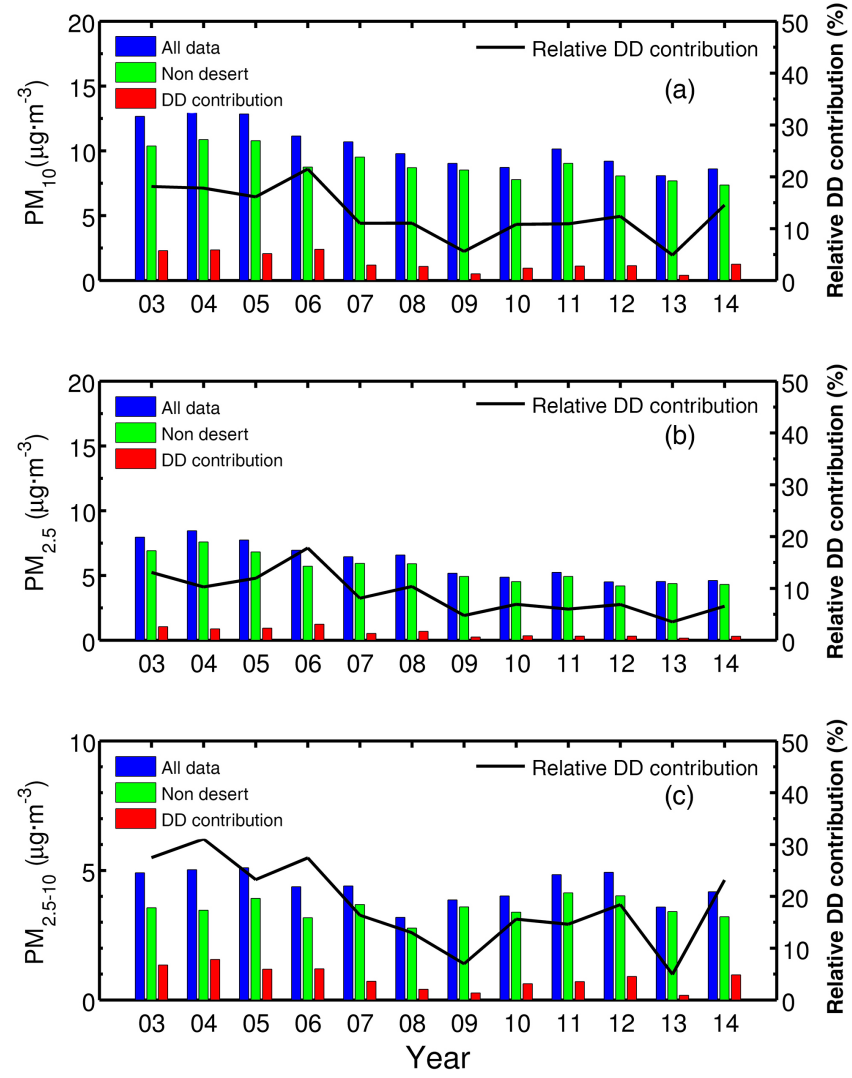

Figure 7. Interannual variability of DD contribution to the total yearly $\mathrm{PM}_{10}(\mathbf{a}), \mathrm{PM}_{2.5}(\mathbf{b})$, and $\mathrm{PM}_{2.5-10}(\mathbf{c})$ in absolute (red bar) and relative values (black line). Blue bars represent the mean year $\mathrm{PM}_{10}$ (a), $\mathrm{PM}_{2.5}$ (b), and $\mathrm{PM}_{2.5-10}$ (c) value and green bars the corresponding values without including the days of desert dust.

two quantities, total AOD and $\mathrm{PM}_{10}$, for the complete dataset follows a similar behaviour between August and March, with differences in April (local PM minimum) and May (local AOD minimum), and a slightly different evolution in JuneJuly. These discrepancies between these quantities lead to a moderately high correlation coefficient of 0.82 between AOD and $\mathrm{PM}_{10}$, but their physical meaning is uncertain, taking into account the discrepancies in the two annual cycles. The seasonal cycles of DD contribution (both absolute and relative), to AOD and $\mathrm{PM}_{10}$ differ in July (with a local minimum of AOD) and September (sharp fall of $\mathrm{PM}_{10}$ ). Furthermore, it is worth mentioning that the maximum of March is more intense for the DD contribution to $\mathrm{PM}_{10}$ than the DD contribution to AOD. Hence, the correlation factors between the DD contribution to $\mathrm{PM}_{10}$ and to AOD are moderately high: 0.84 and 0.74 for the absolute and relative values, respectively.
The fine mode, represented by the $\mathrm{PM}_{2.5}$ data, follows the same pattern as $\mathrm{PM}_{10}$ in the total and DD contribution curves (Table 4 and Fig. 6b). The DD contribution to $\mathrm{PM}_{2.5}$ is below $10 \%$ for most of the year, with a mean value of $\sim 9 \%$.

The total coarse-mode $\left(\mathrm{PM}_{2.5-10}\right)$ curve is also similar to that obtained for the total $\mathrm{PM}_{10}$, although the mean contribution of the DD events is $16 \%$ of the total $\mathrm{PM}_{2.5-10}$, in contrast to the $12 \%$ of the $\mathrm{PM}_{10}$ (see Table 4). The DD contribution to $\mathrm{PM}_{2.5-10}$ (Table 4 and Fig. 6c) exhibits a strong maximum in March $\left(1.7 \mu \mathrm{g} \mathrm{m}^{-3}\right.$ or $\left.33 \%\right)$, a reduction in April and May (around $14 \%)$, large values in June $\left(1.4 \mu \mathrm{g} \mathrm{m}^{-3}\right.$ or $25 \%$ ) followed by a weak decrease in July and August $\left(1.3 \mu \mathrm{g} \mathrm{m}^{-3}\right.$ or $\left.21 \%\right)$, and low values in autumn and winter.

\subsubsection{Interannual variability and trends}

The interannual variations of total $\mathrm{PM}_{10}, \mathrm{PM}_{2.5}$, and $\mathrm{PM}_{2.5-10}$ and the corresponding DD contributions to these $\mathrm{PM}_{x}$ concentrations are plotted in Fig. 7 and reported in Table 5. In the shape of the DD contribution we can distinguish two periods associated with the strong minimum of 2009 . The first period has a decreasing trend from 2003 to 2009 where the first 4 years have similar DD contributions among them. The second period starts with a strong rise of the DD contribution from 2009 to 2012, followed by a significant fall in 2013 and a final rise in 2014. The absolute maximum DD contribution occurs in $2006\left(2.4 \mu \mathrm{g} \mathrm{m}^{-3}\right.$ or $\left.21 \%\right)$ and the absolute minimum is observed in 2013 with $0.4 \mu \mathrm{g} \mathrm{m}^{-3}$ or $5 \%$, although it is very similar to the value in 2009 . The solid line in Fig. 7 illustrating the evolution of the relative contribution highlights the minima of 2005, 2009 and 2013 and the maxima of 2004, 2006, 2012, and 2014.

The interannual evolutions of the total $\mathrm{PM}_{10}$ and $\mathrm{AOD}$ are very similar (see Fig. S2, Supplement) with a correlation coefficient of around 0.9 in 2003-2014. With respect to the yearly values of DD contributions to AOD and $\mathrm{PM}_{10}$, they show a correlation coefficient of 0.81 . The agreement is also quite good for the relative DD contributions to AOD and $\mathrm{PM}_{10}$ (correlation coefficient around 0.7). This high agreement, extremely good during 2009-2013, is not seen for some years. For instance, the reason behind the low DD contribution to AOD in 2006 can be explained by the poor sampling during that year (see Table 1). So far, no reasonable explanation has been found for the strong fall between 2004 and 2005 in the DD contribution to AOD despite the fact that total AOD and $\mathrm{PM}_{10}$ display the same behaviour. The DD contribution to $\mathrm{PM}_{10}$ is notably larger than that obtained for AOD in 2014. The high interannual variability of these quantities highlights the necessity of longer time periods to assess this kind of relationships, bearing in mind that the net contribution of DD aerosols is represented by very low values with a high uncertainty; hence this variability falls within the expected range of change. These results are of interest for long-term studies of columnar and surface aerosol loads in relation to their evolution and trends for climate studies be- 
cause tropospheric aerosols have a strong regional signature and the area studied presents exceptional background conditions representative of the western Mediterranean Basin.

The weak impact of the DD events on the $\mathrm{PM}_{2.5}$ levels (fine mode, see Fig. 7b and Table 5) is reflected in the low relative contribution with only 3 years (2003, 2005, and 2006) presenting values higher than $12 \%$. The last years of the period analysed (2009-2014) present a notable low DD contribution to $\mathrm{PM}_{2.5}$ below $7 \%$. By contrast, $\mathrm{PM}_{2.5-10}$ (Fig. 7c and Table 5) still follows the $\mathrm{PM}_{10}$ pattern. The initial years are the ones with the largest contributions (around $27 \%$ until 2006), while 2013 shows the minimum values (around $5 \%$ ) together with $2009(\sim 7 \%)$.

There is a decreasing trend of all the quantities shown in Fig. 7. The general decrease in $\mathrm{PM}_{x}$ levels has been previously reported for the Peñausende site and for shorter periods (e.g. Barmpadimos et al., 2012; Bennouna et al., 2014; Mateos et al., 2014b; Querol et al., 2014), and it has been corroborated by the temporal trends obtained in this study (see Table 3). Cusack et al. (2012) pointed out a percentage reduction ranging between 7 to $41 \%$ in the yearly $\mathrm{PM}_{2.5}$ from 2002 and 2010 at 11 Spanish sites. To quantify the observed decrease in the DD impact, Table 3 also presents the temporal trends of the DD contribution of $\mathrm{PM}_{10}, \mathrm{PM}_{2.5}$, and $\mathrm{PM}_{2.5-10}$. The general decrease in $\mathrm{PM}_{10}\left(0.46 \mu \mathrm{g} \mathrm{m}^{-3}\right.$ per year, with a $p$ value $<0.01)$ at the Peñausende site for the period 2003 2014 is in line with previous studies (e.g. Querol et al., 2014; Mateos et al., 2015). Regarding the DD contribution, the fall in the three quantities is quantified as around $-10 \%$ per year. In particular, the DD contribution to $\mathrm{PM}_{10}$ has decreased by an absolute amount of $0.14 \mu \mathrm{g} \mathrm{m}^{-3}$ per year ( $p$ value of 0.06 ) and $0.08 \mu \mathrm{g} \mathrm{m}^{-3}$ per year $(p$ value $<0.01)$ for $\mathrm{PM}_{2.5}$. The reduction observed in the DD event days (see Sect. 4.1.3) has also led to a significant fall in total particulate matter. Comparing the temporal trends of the $\mathrm{PM}_{10} \mathrm{DD}$ contribution and the rate for the total quantity, the DD impact has caused $30 \%$ of the total $\mathrm{PM}_{10}$ decrease in north-central Spain. This percentage is smaller (about $21 \%$ ) for the $\mathrm{PM}_{2.5}$ case. In the north-eastern region, Querol et al. (2014) showed that crustal matter accounted for $14 \%$ of the total $\mathrm{PM}_{2.5}$ decrease between 2001 and 2012.

\subsection{Estimation of associated uncertainty of the methodology}

No quantification has been done for the associated uncertainties in the number of events and associated days in most of the literature. The same happens for the uncertainty linked to the DD contribution, which can be evaluated as a consequence of the earlier error of DD detection. One way to estimate a possible range of the real uncertainty is the comparison of results obtained from different methodologies. This task was addressed by the above-mentioned study of Viana et al. (2010) showing relative differences in the number of dusty days of about 12 and $28-50 \%$ for the DD absolute con- tribution. A big step took place when the proposed methodology by Escudero et al. (2007) was taken as the official standard method. However, the 30 days moving percentile used to establish the regional background has been changed from $30 \%$ (reported by Escudero et al., 2007) to $40 \%$ (Pey et al., 2013a; Salvador et al., 2013, 2014). There is evidence that this percentile may be site dependent, thus demonstrating the difficulty of this evaluation. Otherwise, it must be borne in mind that a big difference exists between the Escudero et al. (2007) methodology and that applied by us. This subsection describes a first attempt to estimate the uncertainty associated with the method used in our study.

Fingerprints of each DD event day are visible on at least one of the quantities related to aerosol load (columnar or surface) analysed in the inventory evaluation (see Sect. 3), plus the additional information on air mass back trajectories, satellite images, and synoptic scenarios. Usually, several of these variables simultaneously corroborate the DD presence, especially due to the low background values that characterize the north-central Spanish region. Therefore, the thorough inspection of all the information provided by different sources at the same time causes the error in the DD identification to be minimal. From our experience during these 12 years of data, we consider that possible error sources can be, mainly, the following: gaps in the data series, classification or not of a day when the aerosol load is close to the threshold values, and uncertainty of the instrumental techniques and the ancillary tools. Therefore, we can estimate that about 3-5 days per year could be missed in the annual sum of dusty days. This assumption is based on our long-term expertise in this evaluation when the DD inventory has been re-evaluated to ensure its accuracy. So the associated relative uncertainty, considering the average of 35 DD event days per year, is $\sim 9$ $15 \%$, which is in line with the results reported by Viana et al. (2010) as mentioned above. This estimation gives a realistic range for the error associated with this methodology of visual inspection. The 5 days per year uncertainty (or 15\%) can overestimate the real error, but even this percentage can be considered acceptable as the maximum average error. Regarding the sum of dusty days in the seasonal cycle, the same range of error can be assumed in every monthly interannual value.

The possibility of missing these few days with DD fingerprints $(\sim 3-5$ per year and per interannual month) leads to an uncertainty in the evaluation of the DD contribution to AOD values. Hence, to quantify the uncertainty in the seasonal cycle of the DD contribution to AOD each interannual monthly database is extended adding $9 \%$ of DD event days (considering that 3 days are missed). For these "extra" days the AOD is assumed as the mean value during the DD events in that month. For instance, 4 days are added in June with a mean AOD of 0.27 and 1 day is added in January with $\mathrm{AOD}_{440 \mathrm{~nm}}=0.18$. The DD contribution is calculated for the new data series, evaluating the differences with those values shown in Sect. 4.2 (from the original database). The results 
show a small change in the DD contribution to AOD, always below 0.002. For instance, for June the relative uncertainty caused by the added days is $6.7 \%$ (the absolute DD contribution for the original evaluation is 0.027). However, those months with less absolute DD contribution to AOD cause a relative difference between 15 and $20 \%$ (such as January and December). Overall, the mean uncertainty is 0.0013 or $9.7 \%$ when the uncertainties of the 12 multi-annual monthly values are averaged. This relative uncertainty is in line with the $10 \%$ calculated by receptor modelling studies (Viana et al., 2010). The same procedure is applied for the interannual DD contribution to AOD. On average, the inclusion of $9 \%$ DD extra days causes an uncertainty of 0.0014 or $8.3 \%$. If the assumption of a missing 3 days per year is even increased to 5 days per year, the uncertainties caused regarding the DD contribution to AOD values only increase up to $14 \%$. Hence, the reliability of the method followed here is demonstrated because of the low changes in the results when the DD inventory is augmented with possible dusty days missed.

In the same way, the study of the uncertainties of the DD contribution to $\mathrm{PM}_{10}$ is also addressed with the same method (adding 9-15\% extra DD event days). The results for $\mathrm{PM}_{10}$ indicate a mean uncertainty of $0.1-0.13 \mu \mathrm{g} \mathrm{m}^{-3}$ or $8-14 \%$ in the evaluation of both annual cycle and interannual evolution. Hence, this relative uncertainty can be also extrapolated to the $\mathrm{PM}_{2.5}$ and $\mathrm{PM}_{2.5-10}$ DD contributions showing the feasibility of this method.

\subsection{Analysis of the synoptic scenarios during desert dust episodes}

Using the ancillary information used in the final choice of the DD identification, the synoptic scenarios that favour the arrival of air masses originating in the north of Africa are also studied. These scenarios are those defined and described by Escudero et al. (2005): via the Atlantic Arch (North Africa High located at surface level, NAH-S), directly from northern Africa by deep low pressure (Atlantic Depression, AD) or by a convective system (North African High located at upper levels, NAH-A), and from the Mediterranean area (North African Depression, NAD). Overall, the geographical positions and heights of the high- and low-pressure systems produce the mineral aerosols that reach the IP. Figure 8 presents the annual cycle and interannual variability of the number of episodes associated with each synoptic scenario. The synoptic scenario of each episode has been established considering all the daily meteorological maps during the episode.

The synoptic scenario analysis of the DD events (see Fig. 8a) has shown a predominance of the NAH-A (81 out of 152 episodes), in particular, during the warm season (from May to October). This scenario is produced by an intense solar heating of the Saharan desert. These air masses present large DD loads which can arrive at high altitudes (up to $5 \mathrm{~km}$ a.s.l.). In our study region, the NAH-S scenario governs (38 out of 152 episodes) the DD intrusions between Decem-
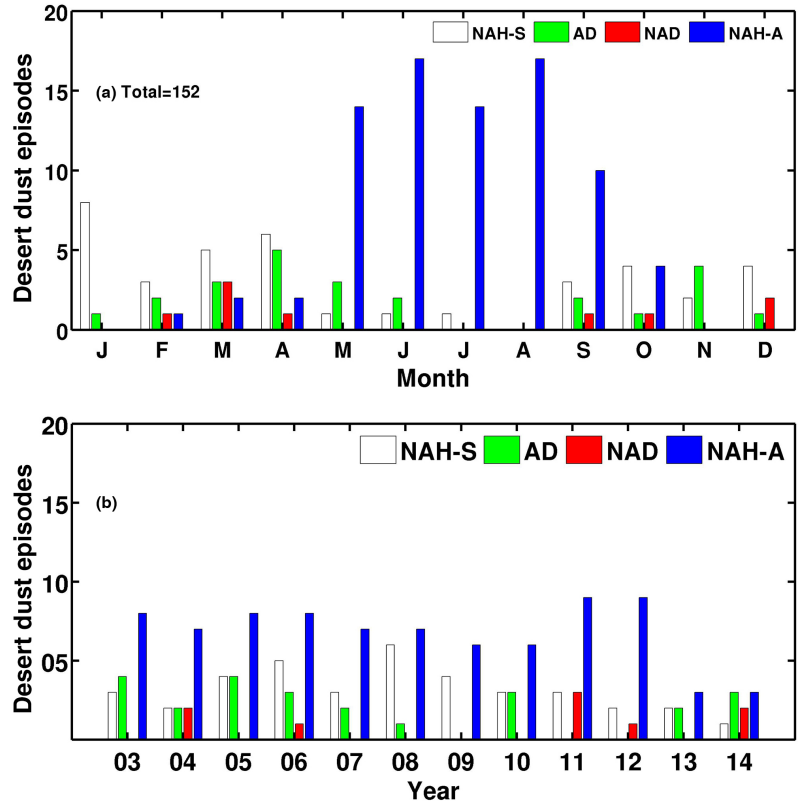

Figure 8. Annual cycle (a) and interannual (b) variability of DD episodes classified in terms of their synoptic scenarios: NAH-S (white bars), AD (green bars), NAD (red bars), and NAH-A (blue bars). The four synoptic scenarios are described in the text (see Sect. 4.5).

ber and April (being also significant in October) and generates transport at the lower atmospheric levels (generally below $1 \mathrm{~km}$ a.s.l.). The $\mathrm{AD}$ scenario plays a minor role ( 24 out of 152 episodes) but with an influence confined to between February and May, September, and November. The NAD scenario only presents an important contribution in March and December (9 out of 152 episodes).

The fingerprints of the evolution of these synoptic scenarios are reflected in the climatology of the DD episodes shown in Fig. 2. The rapid increase in DD events in March (see Fig. 2) is caused by a larger influence of NAH-S (3 to 5 DD events with respect to February), the marked appearance of NAD (3 events), and a slight increase in AD (2 to 3 DD events with respect to February). The synoptic situation in April changes and the NAD scenario almost disappears while NAH-S and AD increase their influence. The local summer minimum in July is caused by the lower occurrence of the NAH-A conditions. Previous studies have found this minimum for other columnar quantities, such as the vertical precipitable water vapour (Ortiz de Galisteo et al., 2013). The absolute DD event minimum of November is caused by the total disappearance of the NAH-A scenario.

Comparing these results with previous inventories performed in other geographical areas of the IP, the synoptic scenario climatology presents some discrepancies. Toledano et al. (2007b) have also found a predominance of the NAH-A conditions during summer for the El Arenosillo site (southwestern IP) in the period 2000-2005. However, the role 
played by the NAH-S seems to be minor during winter compared to the north-central area. The DD inventory in the northern Mediterranean Spanish coast has been analysed by Escudero et al. (2005) between 1996 and 2002. They also obtained the major predominance of the NAH-A during summer, although the NAD scenario shows a notable impact on the DD events in May and November. These outbreaks arriving from the Mediterranean area are also reported in the months of February, March, and November in the El Arenosillo inventory.

The interannual distribution of DD events and the four synoptic scenarios (see Fig. 8b) corroborate the predominance of the synoptic scenario NAH-A every year. Overall, there is a mean of seven episodes per year due to this scenario in the north-central area of the IP, the maximum influence being in 2012 where 9 out 12 events occurred in this situation. A special feature is the simultaneous appearance of the four scenarios only in the years 2004, 2006, and 2014. The last 2 years of the analysed period (2013-2014) have shown a decrease in the number of episodes that can be attributed to the absence of synoptic conditions favouring mineral dust transport during summer (NAH-A scenario). The occurrence of the NAH-S and AD scenarios presents high interannual variability but the number of DD episodes they caused is always smaller than those caused by NAH-A. Finally, NAD conditions in the north-central IP are only relevant in 2004, 2011, and 2014 with 2, 3, and 2 events, respectively. However, this scenario plays a key role in the north-eastern area of the IP (e.g. Escudero et al., 2005), which shows that DD intrusions arriving through the Mediterranean area rarely reach the north-central region of Spain.

\section{Conclusions}

In this study, a methodology to obtain a reliable identification of desert dust (DD) intrusions is proposed and applied to the north-central area of the Iberian Peninsula. Long-term datasets of AOD and $\mathrm{PM}_{x}$ for the background sites of Palencia and Peñausende (representative of the study area) have been used as core information for the detection of desert dust intrusions in this area during an 12-year period (from January 2003 to December 2014). The analysis of ancillary information, such as air mass back trajectories at three altitude levels (500, 1500, and $3000 \mathrm{~m}$ a.s.1.), MODIS-AOD and true-colour images, and meteorological maps, has been used to establish the duration of each desert dust episode, creating a reliable inventory of desert dust episodes. The main conclusions can be summarized as follows:

1. The simultaneous consideration of surface and columnar aerosols has been shown to be a reliable tool in DD identification. More than half of the inventory has been detected by $\mathrm{AOD}_{440 \mathrm{~nm}}$ and $\mathrm{PM}_{10}$ data at the same time. However, each quantity can provide DD detection by itself in a large number of cases (114 and 80 out of
418 days detected by only $\mathrm{PM}_{10}$ and AOD data, respectively). The smaller coverage of AOD sampling is not a major handicap in this process.

2. A total of 152 episodes composed of 418 days presented desert dust aerosols during the entire period. The annual cycles of the number of DD episodes and days follow a similar pattern: an increase in March, a weak fall of event days in April, a notable increment between May and September, and a progressive decline to the absolute minimum in winter, with the absolute maximum in June and local minimum in July or August. Interannual variability of the number of DD episodes and dusty days is high, ranging between 7 episodes (15 dusty days) in 2013 and 17 episodes (67 dusty days) in 2006. A temporal trend of -2.7 dusty days per year $(95 \%$ significance level) highlights the decrease between 2003 and 2014. Therefore, a reduction in the DD outbreaks in the northcentral area of the Iberian Peninsula is found during the period studied.

3. Overall, the mean DD contribution to $\mathrm{AOD}_{440 \mathrm{~nm}}$ is 0.015 or $11.5 \%$, while for the surface concentration $\mathrm{PM}_{10}, \mathrm{PM}_{2.5}$, and $\mathrm{PM}_{2.5-10}$ this is $1.3 \mu \mathrm{g} \mathrm{m}^{-3}(11.8 \%)$, $0.55 \mu \mathrm{g} \mathrm{m}^{-3}$ (8.5), and $0.79 \mu \mathrm{g} \mathrm{m}^{-3}(16.1 \%)$, respectively.

4. The annual cycle of the DD contribution to the aerosol load peaks in March, decreases in April-May, notably increases during summer months (the AOD curve has a local minimum in July), and experiences a progressive decline after summer (with a significant fall in September for the $\mathrm{PM}_{10}$ curve) towards minimum values in winter. The maximum DD contribution to AOD occurs in June and August close to 0.03, while the $\mathrm{PM}_{10}$ maximum DD contribution reaches $\sim 2.4 \mu \mathrm{g} \mathrm{m}^{-3}$ in August.

5. The interannual variability of the DD contribution to the aerosol load is at a maximum in 2004 for AOD with 0.03 and 2006 for $\mathrm{PM}_{10}$ with $2.4 \mu \mathrm{g} \mathrm{m}^{-3}$ and at a minimum in $2013\left(0.004\right.$ for $\mathrm{AOD}_{440 \mathrm{~nm}}$ and $0.4 \mu \mathrm{g} \mathrm{m}^{-3}$ for $\mathrm{PM}_{10}$ ). The correlation coefficient between the DD contribution to $\mathrm{AOD}_{440 \mathrm{~nm}}$ and $\mathrm{PM}_{10}$ yearly means is 0.81 .

6. The temporal trends of the DD contribution to AOD, $\mathrm{PM}_{10}$, and $\mathrm{PM}_{2.5}$ have values of -0.0019 ( $p$ value of 0.02 ), $-0.14 \mu \mathrm{g} \mathrm{m}^{-3}$ ( $p$ value of 0.06 ) per year, and $-0.08 \mu \mathrm{g} \mathrm{m}^{-3}$ ( $p$ value $<0.01$ ) per year in the analysed period, respectively. All these negative rates indicate a decrease in the levels of natural mineral dust aerosols, which represents around $30 \%$ of the total aerosol load decrease shown by AOD (columnar) and $\mathrm{PM}_{10}$ (surface) in 2003-2014. This decrease is around $20 \%$ for the $\mathrm{PM}_{2.5}$ case.

7. DD outbreaks have mainly reached the north-central Iberian Peninsula directly from northern Africa by a 
convective system (NAH-A synoptic scenario), with clear predominance in the summer months. The NAH-S (via the Atlantic Arch) and AD (directly from northern Africa by a deep low pressure) scenarios present a variable influence thorough the year, while the NAD (from the Mediterranean area) conditions are only important in March and December.

The proposed inventory is the first one based on longterm AOD-PM data series. The use of worldwide networks (EMEP and AERONET) ensures that this method can be implemented in other regions with background aerosol observations, as long as nearby $\mathrm{PM}_{x}$ and AOD measurement sites in clear remote (background) locations are analysed.

With careful inspection of all the information, the inventory can be a useful tool to develop and validate automated methodologies which use other instruments such as Raman lidars and ceilometers or which use model forecasts. The comparison between different methodologies allows a more reliable estimation of uncertainties in DD detection and its contribution to total aerosol load. Future studies based on this inventory will be focused on a global characterization of microphysical and radiative properties of desert dust including the evaluation of its radiative forcing over the study region. Therefore, these results are useful for assessing regional climate change studies linked to atmospheric aerosols because of the excellent clean background conditions of the area, which may be considered one of the few sites or areas in south-western Europe with these conditions.

\section{Data availability}

Data used in this study are freely available from AERONET and EMEP networks. The specific inventory dataset is the intellectual property of the research group that carried out this work.

\section{The Supplement related to this article is available online at doi:10.5194/acp-16-8227-2016-supplement.}

\footnotetext{
Acknowledgements. The authors are grateful to Spanish MINECO for the financial support of the FPI grant BES-2012-051868 and project CGL2012-33576. Thanks are due to EMEP (especially to MAGRAMA and AEMET) and AERONET-PHOTONS-RIMA staff for providing observations and for the maintenance of the networks. The research leading to these results has received funding from the European Union Seventh Framework Programme (FP7/2007-2013) under grant agreement Nr. 262254 [ACTRIS 2]. We also thank "Consejería de Fomento y Medio Ambiente" for their support to desert dust studies in the Castilla y León region, as well as "Consejería de Educación of Junta de Castilla y León" for financing the project (VA100U14).
}

Edited by: W. Lahoz

\section{References}

Aas, W., Espen Yttri, K., Stohl, A. , Lund Myhre, C., Karl, M., Tsyro, S., Marecková, K., Wankmüller, R., Klimont, Z., Heyes, C., Alastuey, A., Querol, X., Pérez, N., Moreno, T., Lucarelli, F., Areskoug, H., Balan, V., Cavalli, F., Putaud, J. P., Cape, J. N., Catrambone, M., Ceburnis, D., Conil, S., Gevorgyan, L., Jaffrezo, J. L., Hueglin, C., Mihalopoulos, N., Mitosinkova, M., Riffault, V., Sellegri, K., Spindler, G., Schuck, T., Pfeffer, U., Breuer, L., Adolfs, D., Chuntonova, L., Arabidze, M., and Abdulazizov, E.: Transboundary particulate matter in Europe Status report 2013, EMEP Report, 4/2013 (Ref. O-7726), 2013.

Alados-Arboledas, L., Lyamani, H., and Olmo, F. J.: Aerosol size properties at Armilla, Granada (Spain), Q. J. Roy. Meteor. Soc., 129, 1395-1413, doi:10.1256/qj.01.207, 2003.

Barmpadimos, I., Keller, J., Oderbolz, D., Hueglin, C., and Prévôt, A. S. H.: One decade of parallel fine (PM2.5) and coarse $\left(\mathrm{PM}_{10}-\mathrm{PM}_{2.5}\right)$ particulate matter measurements in Europe: trends and variability, Atmos. Chem. Phys., 12, 3189-3203, doi:10.5194/acp-12-3189-2012, 2012.

Basart, S., Pérez, C., Cuevas, E., Baldasano, J. M., and Gobbi, G. P.: Aerosol characterization in Northern Africa, Northeastern Atlantic, Mediterranean Basin and Middle East from direct-sun AERONET observations, Atmos. Chem. Phys., 9, 8265-8282, doi:10.5194/acp-9-8265-2009, 2009.

Bègue, N., Tulet, P., Chaboureau, J. P., Roberts, G., Gomes, L., and Mallet, M.: Long-range transport of Saharan dust over northwestern Europe during EUCAARI 2008 campaign: Evolution of dust optical properties by scavenging, J. Geophys. Res., 117, D17201, doi:10.1029/2012JD017611, 2012.

Belis, C. A., Karagulian, F., Larsen, B. R., and Hopke, P. K.: Critical review and met-analysis of ambient particulate matter source apportionment using receptor models in Europe, Atmos Environ., 69, 94-108, doi:10.1016/j.atmosenv.2012.11.009, 2013.

Bennouna, Y. S., Cachorro, V. E., Torres, B., Toledano, C., Berjón, A., de Frutos, A. M., and Alonso Fernández Coppel, I.: Atmospheric turbidity determined by the annual cycle of the aerosol optical depth over north-center Spain from ground (AERONET) and satellite (MODIS), Atmos. Environ., 67, 352364, doi:10.1016/j.atmosenv.2012.10.065, 2013.

Bennouna, Y. S., Cachorro, V., Burgos, M. A., Toledano, C., Torres, B., and de Frutos, A.: Relationships between columnar aerosol optical properties and surface particulate matter observations in north-central Spain from long-term records (2003-2011), Atmos. Meas. Tech. Discuss., 7, 5829-5882, doi:10.5194/amtd-7-58292014, 2014.

Boselli, A., Caggiano, R., Cornacchia, C., Madonna, F., Mona, L., Macchiato, M., Pappalardo, G., and Trippeta, S.: Multi year sun-photometer measurements for aerosol characterization in a Central Mediterranean site, Atmos. Res., 104-105, 98-110, doi:10.1016/j.atmosres.2011.08.002, 2012.

Boucher, O., Randall, D., Artaxo, P., Bretherton, C., Feingold, G., Forster, P., Kerminen, V. M., Kondo, Y., Liao, H., Lohmann, U., Rasch, P., Satheesh, S. K., Sherwood, S., Stevens, B., and Zhang, X. Y.: Clouds and aerosols, in: Climate Change 2013: The Phys- 
ical Science Basis, Contribution of Working Group I to the Fifth Assessment Report of the Intergovernmental Panel on Climate Change, edited by: Stocker, T. F., Qin, D., Plattner, G.-K., Tignor, M., Allen, S. K., Boschung, J., Nauels, A., Xia, Y., Bex, V., and Midgley, P. M., 571-657, Cambridge University Press, Cambridge, United Kingdom and New York, NY, USA, 2013.

Cachorro, V. E., Durán, P., Vergaz, R., and de Frutos, A. M.: Columnar physical and radiative properties of atmospheric aerosols in north central Spain, J. Geophys. Res., 105, 7161-7175, doi:10.1029/1999JD901165, 2000.

Cachorro, V. E., Vergaz, R., de Frutos, A. M., Vilaplana, J. M., Henriques, D., Laulainen, N., and Toledano, C.: Study of desert dust events over the southwestern Iberian Peninsula in year 2000: two case studies, Ann. Geophys., 24, 1493-1510, doi:10.5194/angeo24-1493-2006, 2006.

Cachorro, V. E., Toledano, C., Prats, N., Sorribas, M., Mogo, S., Berjón, A., Torres, B., Rodrigo, R., de la Rosa, J., and De Frutos, A. M.: The strongest desert dust intrusion mixed with smoke over the Iberian Peninsula registered with Sun photometry, J. Geophys. Res., 113, D14S04, doi:10.1029/2007JD009582, 2008.

Córdoba-Jabonero, C., Sorribas, M., Guerrero-Rascado, J. L., Adame, J. A., Hernández, Y., Lyamani, H., Cachorro, V., Gil, M., Alados-Arboledas, L., Cuevas, E., and de la Morena, B.: Synergetic monitoring of Saharan dust plumes and potential impact on surface: a case study of dust transport from Canary Islands to Iberian Peninsula, Atmos. Chem. Phys., 11, 3067-3091, doi:10.5194/acp-11-3067-2011, 2011.

Cusack, M., Alastuey, A., Pérez, N., Pey, J., and Querol, X.: Trends of particulate matter $\left(\mathrm{PM}_{2.5}\right)$ and chemical composition at a regional background site in the Western Mediterranean over the last nine years (2002-2010), Atmos. Chem. Phys., 12, 8341-8357, doi:10.5194/acp-12-8341-2012, 2012.

d'Almeida, G., Koepke, P., and Shettle, E.: Atmospheric Aerosols: Global Climatology and Radiative Characteristics, Studies in Geophysical Optics and Remote Sensing, A. Deepak Pub., Hampton, Va, 561 pp., 1991.

di Sarra, A., Di Biagio, C., Meloni, D., Monteleone, F., Pace, G., Pugnaghi, S., and Sferlazzo, D.: Shortwave and longwave radiative effects of the intense Saharan dust event of 25-26 March 2010 at Lampedusa (Mediterranean Sea), J. Geophys. Res., 116, D23209, doi:10.1029/2011JD016238, 2011.

Draxler, R. A., Stunder, B., Rolph, G., Stein, A., and Taylor, A.: HYSPLIT4 User's Guide, Air Resources Laboratory, National Oceanic and Atmospheric Administration (NOAA), Silver Spring, MD, 2014.

Dubovik, O., Holben, B. N., Eck, T. F., Smirnov, A., Kaufman, Y. J., King, M. D., Tanré, D., and Slutsker, I.: Variability of absorption and optical properties of key aerosol types observed in worldwide locations, J. Atmos. Sci., 59, 590-608, 2002.

EC: Directive 2008/50/EC of the European Parliament and of the Council (21 May 2008) on Ambient Air Quality and Cleaner Air for Europe, Official Journal of the European Communities, L 151, 1-44, available at: http://eur-lex.europa.eu/legal-content/ EN/TXT/?uri=CELEX:32008L0050 (last access: 7 December 2015), 2008.

Eck, T. F., Holben, B. N., Reid, J. S., Dubovik, O., Smirnov, A., O'Neill, N. T., Slutsker, I., and Kinne, S.: The wavelength dependence of theoptical depth of biomass burning, urban and desert dust aerosols, J. Geophys. Res., 104, 31333-31350, 1999.
Eck, T. F., Holben, B. N., Sinyuk, A., Pinker, R. T., Goloub, P., Chen, H., Chatenet, B., Li, Z.. Singh, R. P., Tripathi, S. N., Reid, J. S., Giles, D. M., Dubovik, O., O’Neill, N. T., Smirnov, A., Wang, P., and Xia, X.: Climatological aspects of the optical properties of fine/coarse mode aerosol mixtures, J. Geophys. Res., 115, D19205, doi:10.1029/2010JD014002, 2010.

Engelstaedter, S. and Washington, R.: Atmospheric controls on the annual cycle of North African dust, J. Geophys. Res., 112, D03103, doi:10.1029/2006JD007195, 2007.

Escudero, M., Castillo, S., Querol, X., Avila, A., Alarcón, M., Viana, M. M., Alastuey, A., Cuevas, E., and Rodríguez, S.: Wet and dry African dust episodes over eastern Spain, J. Geophys. Res., 110, D18S08, doi:10.1029/2004JD004731, 2005.

Escudero, M., Stein, A., Draxler, R. R., Querol, X., Alastuey, A., Castillo, S., and Avila, A.: Determination of the contribution of northern Africa dust source areas to $\mathrm{PM}_{10}$ concentrations over the central Iberian Peninsula using the hybrid single-particle lagrangian integrated trajectory model (HYSPLIT) model, J. Geophys. Res., 111, D06210, doi:10.1029/2005JD006395, 2006.

Escudero, M., Querol, X., Pey, J., Alastuey, A., Pérez, N., Ferreira, F., Alonso, S., and Cuevas, E.: A methodology for the quantification of the net African dust load in air quality monitoring networks, Atmos. Environ., 41, 5516-5524, doi:10.1016/j.atmosenv.2007.04.047, 2007.

Escudero, M., Stein, A. F., Draxler, R. R., Querol, X., Alastuey, A., Castillo, S., and Avila, A.: Source apportionment for African dust outbreaks over the western Mediterranean using the HYSPLIT model, Atmos. Res., 99, 518-527, doi:10.1016/j.atmosres.2010.12.002, 2011.

Estellés, V., Martínez-Lozano, J. A., Utrillas, M. P., and Campanelli, M.: Columnar aerosol properties in Valencia (Spain) by ground-based Sun photometry, J. Geophys. Res., 112, D11201, doi:10.1029/2006JD008167, 2007.

Ganor, E., Stupp, A., and Alpert, P.: A method to determine the effct of mineral dust aerosol on air quality. Atmos. Environ., 43, 5463-5468, doi:10106/j.atmosenv.2009.07.028, 2009.

Gkikas, A., Hatzianastassiou, N., Mihalopoulos, N., Katsoulis, V., Kazadzis, S., Pey, J., Querol, X., and Torres, O.: The regime of intense desert dust episodes in the Mediterranean based on contemporary satellite observations and ground measurements, Atmos. Chem. Phys., 13, 12135-12154, doi:10.5194/acp-1312135-2013, 2013.

Gkikas, A., Basart, S., Hatzianastassiou, N., Marinou, E., Amiridis, V., Kazadzis, S., Pey, J., Querol, X., Jorba, O., Gassó, S., and Baldasano, J. M.: Mediterranean desert dust outbreaks and their vertical structure based on remote sensing data, Atmos. Chem. Phys. Discuss., 15, 27675-27748, doi:10.5194/acpd-15-276752015, 2015.

Goudie, A. S. and Middleton, N. J.: Desert Dust in the Global System, Springer-Verlag Berlin Heidelberg, Berlin, Germany, 288 pp., 2006.

Guerrero-Rascado, J. L., Olmo, F. J., Avilés-Rodríguez, I., NavasGuzmán, F., P'erez-Ra'irez, D., Lyamani, H., and Alados Arboledas, L.: Extreme Saharan dust event over the southern Iberian Peninsula in september 2007: active and passive remote sensing from surface and satellite, Atmos. Chem. Phys., 9, 84538469, doi:10.5194/acp-9-8453-2009, 2009.

Guirado, C., Cuevas, E., Cachorro, V. E., Toledano, C., AlonsoPérez, S., Bustos, J. J., Basart, S., Romero, P. M., Camino, 
C., Mimouni, M., Zeudmi, L., Goloub, P., Baldasano, J. M., and de Frutos, A. M.: Aerosol characterization at the Saharan AERONET site Tamanrasset, Atmos. Chem. Phys., 14, 1175311773, doi:10.5194/acp-14-11753-2014, 2014.

Haywood, J. M. and Boucher, O.: Estimates of the direct and indirect radiative forcing due to tropospheric aerosols: A review, Rev. Geophys., 38, 513-543, doi:10.1029/1999RG000078, 2000.

Hogan, T. and Rosmond, T.: The description of the Navy Operational Global Atmospheric Predictions System's spectral forecast model, Mon. Weather Rev., 119, 1786-1815, doi:10.1175/15200493(1991)119<1786:TDOTNO>2.0.CO;2, 1991.

Holben, B. N., Eck, T. F., Slutsker, I., Tanré, D., Buis, J. P., Setzer, A., Vermote, E., and Smirnov, A.: AERONET - A federated instrument network and data archive for aerosol characterization, Remote Sens. Environ., 66, 1-16, doi:10.1016/S00344257(98)00031-5, 1998.

Kalivitis, N., Gerasopoulos, E., Vrekousis, M., Kouvarakis, G., Kubilay, N., Hatzianastassiou, N., Vardavas, I., and Mihalopoulos, N.: Dust transport over the Eastern Mediterranean from TOMS, AERONET and surface measurements, J. Geophys. Res., 112, D03202, doi:10.1029/2006JD007510, 2007.

Kallos, G., Papadopoulos, A., and Katsafados, P.: Model-derived seasonal amounts of dust deposited on Mediterranean Sea and Europe. In Building the European Capacity in Operational Oceanography. Proceedings of the Third International Conference on EuroGOOS, Athens, Greece 3-6 December 2002, edited by: Dahlin, H., Flemming, N. C., Nittis, K., and Petersson, S. E., Elsevier Oceanography Series, 69, 57-63, 2003.

Kaskaoutis, D., Kambezidis, H., Nastos, P., and Kosmopoulos, P.: Study on an intense dust storm over Greece, Atmos. Environ., 42, 6884-6896, 2008.

Kaskaoutis, D. G., Kosmopoulos, P. G., Nastos, P. T., Kambezidis, H. D., Sharma, M., and Mehdi, W.: Transport pathways of Sahara dust over Athens, Greece as detected by MODIS and TOMS, Geomat. Nat. Hazards Risk, 3, 35-54, 2012.

Kaufman, Y. J., Koren, I., Remer, L. A., Tanré, D., Ginoux, P., and Fan, S.: Dust transport and deposition observed from the terramoderate resolution imaging spectroradiometer (MODIS) spacecraft over the Atlantic ocean, J. Geophys. Res., 110, D10S12, doi:10.1029/2003JD004436, 2005.

Knippertz, P. and Stuut, J.-B. W.: Mineral Dust: A Key Player in the Earth System, Springer Netherlands. Dordrecht, Netherlands, 509 pp., 2014.

Knippertz, P. and Todd, M.C.: Mineral dust aerosols over the Sahara: Meteorological controls on emission and transport and implications for modeling, Rev. Geophys., 50, RG1007, doi:10.1029/2011RG000362, 2012.

Kulmala, M., Asmi, A., Lappalainen, H. K., Carslaw, K. S., Pöschl, U., Baltensperger, U., Hov, Ø., Brenquier, J.-L., Pandis, S. N., Facchini, M. C., Hansson, H.-C., Wiedensohler, A., and O'Dowd, C. D.: Introduction: European Integrated Project on Aerosol Cloud Climate and Air Quality interactions (EUCAARI) - integrating aerosol research from nano to global scales, Atmos. Chem. Phys., 9, 2825-2841, doi:10.5194/acp-9-2825-2009, 2009.

Lohmann, U. and Feichter, J.: Global indirect aerosol effects: a review, Atmos. Chem. Phys., 5, 715-737, doi:10.5194/acp-5-7152005, 2005.
Lohmann, U., Rotstayn, L., Storelvmo, T., Jones, A., Menon, S., Quaas, J., Ekman, A. M. L., Koch, D., and Ruedy, R.: Total aerosol effect: radiative forcing or radiative flux perturbation?, Atmos. Chem. Phys., 10, 3235-3246, doi:10.5194/acp-10-32352010, 2010.

Lyamani, H., Olmo, F. J., and Alados-Arboledas, L.: Saharan dust outbreak over southeastern Spain as detected by sun photometer, Atmos. Environ., 39, 7276-7284, doi:10.1016/j.atmosenv.2005.09.011, 2005.

MAGRAMA: Ministerio de Agricultura, Alimentación y Medio Ambiente. "Procedimiento para la identificación de episodios naturales de $\mathrm{PM}_{10}$ y $\mathrm{PM}_{2.5}$, y la demostración de causa en lo referente a las superaciones del valor límite diario de $\mathrm{PM}_{10}$ ", Madrid, Spain, Abril 2013, available at: http://www.magrama.gob.es/es/calidad-y-evaluacion-ambiental/ temas/atmosfera-y-calidad-del-aire/Metodolog\%C3\%ADa_ para_episodios_naturales_2012_tcm7-281402.pdf (last access: 7 December 2015), 2013.

MAGRAMA: Ministerio de Agricultura, Alimentación y Medio Ambiente, "Episodios naturales de particulas 2014", Madrid, Spain. Abril 2015, available at: http://www.magrama.gob.es/es/calidad-y-evaluacion-ambiental/ temas/atmosfera-y-calidad-del-aire/episodiosnaturales2014 tcm7-379247.pdf (last access: 7 December 2015), 2015.

Mahowald, N. M., Kloster, S., Engelstaedter, S., Moore, J. K., Mukhopadhyay, S., McConnell, J. R., Albani, S., Doney, S. C., Bhattacharya, A., Curran, M. A. J., Flanner, M. G., Hoffman, F. M., Lawrence, D. M., Lindsay, K., Mayewski, P. A., Neff, J., Rothenberg, D., Thomas, E., Thornton, P. E., and Zender, C. S.: Observed 20th century desert dust variability: impact on climate and biogeochemistry, Atmos. Chem. Phys., 10, 10875-10893, doi:10.5194/acp-10-10875-2010, 2010.

Mateos, D., Antón, M., Toledano, C., Cachorro, V. E., AladosArboledas, L., Sorribas, M., Costa, M. J., and Baldasano, J. M.: Aerosol radiative effects in the ultraviolet, visible, and nearinfrared spectral ranges using long-term aerosol data series over the Iberian Peninsula, Atmos. Chem. Phys., 14, 13497-13514, doi:10.5194/acp-14-13497-2014, 2014a.

Mateos, D., Sanchez-Lorenzo, A., Antón, M., Cachorro, V. E., Calbo, J., Costa, M. J., Torres, B., and Wild, M.: Quantifying the respective roles of aerosols and clouds in the strong brigthening since the early 2000 s over the Iberian Peninsula, J. Geophys. Res. Atmos., 119, 10382-10393, doi:10.1002/2014JD022076, 2014b.

Mateos, D., Cachorro, V. E., Toledano, C., Burgos, M. A., Bennouna, Y., Torres, B., Fuertes, D., González, R., Guirado, C., Calle, A., and de Frutos, A. M.: Columnar and surface aerosol load over the Iberian Peninsula establishing annual cycles, trends, and relationships in five geographical sectors, Sci. Total Environ., 518-519, 378-392, doi:10.1016/j.scitotenv.2015.03.002, 2015.

Meloni, D., di Sarra, A., Biavati, G., DeLuisi, J. J., Monteleone, F., Pace, G., Piacentino, S., and Sferlazzo, D. M.: Seasonal behavior of Saharan dust events at the Mediterranean island of Lampedusa in the period 1999-2005, Atmos. Env., 41, 30413056, doi:10.1016/j.atmosenv.2006.12.001, 2007.

Mona, L., Amodeo, A., Pandolfi, M., and Pappalardo, G.: Saharan dust intrusions in the mediterranean area: Three years of raman lidar measurements, J. Geophys. Res., 111, D16203, doi:10.1029/2005JD006569, 2006. 
Mona, L., Papagiannopoulos, N., Basart, S., Baldasano, J., Binietoglou, I., Cornacchia, C., and Pappalardo, G.: EARLINET dust observations vs. BSC-DREAM8b modeled profiles: 12year-long systematic comparison at Potenza, Italy, Atmos. Chem. Phys., 14, 8781-8793, doi:10.5194/acp-14-8781-2014, 2014.

Obregón, M. A., Pereira, S., Wagner, F., Serrano, A., Cancillo, M. L., and Silva, A. M.: Regional differences of column aerosol parameters in western Iberian Peninsula, Atmos. Environ., 62, 208219, doi:10.1016/j.atmosenv.2012.08.016, 2012.

O’Neill, N. T., Eck, T. F., Smirnov, A., Holben, B. N., and Thulasiraman, S.: Spectral discrimination of coarse and fine mode optical depth, J. Geophys. Res., 108, 4559, doi:10.1029/2002JD002975, 2003.

Ortiz de Galisteo, J. P., Bennouna, Y., Toledano, C., Cachorro, V., Romero, P., Andrés, M. I., and Torres, B.: Analysis of the annual cycle of the precipitable water vapour over Spain from 10-year homogenized series of GPS data, Q. J. Roy. Meteor. Soc., 140, 397-406, doi:10.1002/qj.2146, 2013.

Pace, G., di Sarra, A., Meloni, D., Piacentino, S., and Chamard, P.: Aerosol optical properties at Lampedusa (Central Mediterranean). 1. Influence of transport and identification of different aerosol types, Atmos. Chem. Phys., 6, 697-713, doi:10.5194/acp-6-697-2006, 2006.

Papayannis, A., Amiridis, V., Mona, L., Tsaknakis, G., Balis, D., Bosenberg, J., Chaikovski, A., De Tomasi, F., Grigorov, I., Mattis, I., Mitev, V., Muller, D., Nickovic, S., Perez, C., Pietruczuk, A., Pisani, G., Ravetta, F., Rizi, V., Sicard, M., Trickl, T., Wiegner, M., Gerding, M., Mamouri, R. E., D’Amico, G., and Pappalardo, G.: Systematic lidar observations of Saharan dust over Europe in the frame of EARLINET (2000-2002), J. Geophys. Res., 113, D10204, doi:10.1029/2007jd009028, 2008.

Pérez, C., Nickovic, S., Baldasano, J. M., Sicard, M., Rocadenbosch, F., and Cachorro, V. E.: A long Saharan dust event over the western mediterranean: Lidar, sun photometer observations, and regional dust modeling, J. Geophys. Res., 111, D15214, doi:10.1029/2005JD006579, 2006.

Pérez, L., Tobías, A., Querol, X., Pey, J., Alastuey, A., Díaz, J., and Sunyer, J.: Saharan dust, particulate matter and cause-specific mortality: A case-crossover study in Barcelona (Spain), Environ. Int., 48, 150-155, doi:10.1016/j.envint.2012.07.001, 2012.

Pey, J., Querol, X., Alastuey, A., Forastiere, F., and Stafoggia, M.: African dust outbreaks over the Mediterranean Basin during 2001-2011: $\mathrm{PM}_{10}$ concentrations, phenomenology and trends, and its relation with synoptic and mesoscale meteorology, Atmos. Chem. Phys., 13, 1395-1410, doi:10.5194/acp-13-13952013, 2013a.

Pey, J., Alastuey, A., and Querol, X.: $\mathrm{PM}_{10}$ and $\mathrm{PM}_{2.5}$ source at the insular location in the western Mediterranean by using source apportionment techniques, Sci. Total Environ., 456-457, 267-277, doi:10.1016/j.scitotenv.2013.03.084, 2013b.

Pope, C. A.: Review: Epidemiological basis for particulate air pollution health standards, Aerosol Sci. Tech., 31, 4-14, doi:10.1080/027868200303885, 2000.

Prospero, J. M.: Long-term measurements of the transport of African mineral dust to the Southeastern United States: Implications for regional air quality, J. Geophys. Res., 104, 15.91715.927, doi:10.1029/1999JD900072, 1999.

Prospero, J. M., Ginoux, P., Torres, O., Nicholson, S. E., and Gill, T. E.: Environmental characterization of global sources of atmo- spheric soil dust identified with the nimbus 7 total ozone mapping spectrometer (TOMS) absorbing aerosol product, Rev. Geophys., 40, 2-1-2-31, doi:10.1029/2000RG000095, 2002.

Querol, X., Pey, J., Pandolfi, M., Alastuey, A., Cusack, M., Pérez, N., Moreno, T., and Kleanthous, S.: African dust contributions to mean ambient $\mathrm{PM}_{10}$ mass-levels across the Mediterranean Basin, Atmos. Environ., 43, 4266-4277, doi:10.1016/j.atmosenv.2009.06.013, 2009.

Querol, X., Alastuey, A., Viana, M., Moreno, T., Reche, C., Minguillón, M. C., Ripoll, A., Pandolfi, M., Amato, F., Karanasiou, A., Pérez, N., Pey, J., Cusack, M., Vázquez, R., Plana, F., Dall'Osto, M., de la Rosa, J., Sánchez de la Campa, A., Fernández-Camacho, R., Rodríguez, S., Pio, C., AladosArboledas, L., Titos, G., Artínano, B., Salvador, P., García Dos Santos, S., and Fernández Patier, R.: Variability of carbonaceous aerosols in remote, rural, urban and industrial environments in Spain: implications for air quality policy, Atmos. Chem. Phys., 13, 6185-6206, doi:10.5194/acp-13-6185-2013, 2013.

Querol, X., Alastuey, A., Pandolfi, M., Reche, C., Pérez, N., Minguillón, M. C., Moreno, T., Viana, M., Escudero, M., Orio, A., Pallarés, M., and Reina, F.: 2001-2012 trends on air quality in Spain, Sci. Total Environ., 490, 957-969, doi:10.1016/j.scitotenv.2014.05.074, 2014.

Rodríguez, S., Querol, X., Alastuey, A., Kallos, G., and Kakaliagou, O.: Saharan dust contributions to $\mathrm{PM}_{10}$ and TSP levels in Southern and Eastern Spain, Atmos. Environ., 35, 2433-2447, doi:10.1016/S1352-2310(00)00496-9, 2001.

Rodríguez, S., Querol, X., Alastuey, A., and Plana, F.: Sources and processes affecting levels and composition of atmospheric aerosol in the western Mediterranean, J. Geophys. Res., 107, 4777, doi:10.1029/2001JD001488, 2002.

Rodríguez, S., Cuevas, E., Prospero, J. M., Alastuey, A., Querol, X., López-Solano, J., García, M. I., and Alonso-Pérez, S.: Modulation of Saharan dust export by the North African dipole, Atmos. Chem. Phys., 15, 7471-7486, doi:10.5194/acp-15-74712015, 2015.

Salvador, P., Artiñano, B., Molero, F., Viana, M., Pey, J., Alastuey, A., and Querol, X.: African Dust Contribution to Ambient Aerosol Levels Across Central Spain: Characterization of LongRange Transport Episodes of Desert Dust, Atmos. Res., 127, 117-129, doi:10.1016/j.atmosres.2011.12.011, 2013.

Salvador, P., Alonso-Pérez, S., Pey, J., Artíñano, B., de Bustos, J. J., Alastuey, A., and Querol, X.: African dust outbreaks over the western Mediterranean Basin: 11-year characterization of atmospheric circulation patterns and dust source areas, Atmos. Chem. Phys., 14, 6759-6775, doi:10.5194/acp-14-6759-2014, 2014.

Sanchez-Lorenzo, A., Calbó, J., and Wild, M.: Global and diffuse solar radiation in Spain: Building a homogeneous dataset and assessing trends, Global Planet. Change, 100, 343-352, doi:10.1016/j.gloplacha.2012.11.010, 2013.

Stein, A., Draxler, R., Rolph, G., Stunder, B., Cohen, M., and Ngan, F.: NOAA's HYSPLIT atmospheric transport and dispersion modeling system, Bull. Am. Meteorol. Soc., 96, 2059-2077, doi:10.1175/BAMS-D-14-00110.1, 2015.

Su, L., Yuan, Z., Fung, J. C. H., and Lau, A. K. H.: A comparison of HYSPLIT backward trajectories generated from two GDAS datasets, Sci. Total Environ., 506-507, 527-537, 2015. 
Tafuro, A. M., Barnaba, F., De Tomasi, F., Perrone, M. R., and Gobbi, G. P.: Saharan dust particle properties over the central Mediterranean, Atmos. Res., 81, 67-93, 2006.

Toledano, C., Cachorro, V. E., Berjon, A., de Frutos, A. M., Sorribas, M., de la Morena, B., and Goloub, P.: Aerosol optical depth and Ångström exponent climatology at El Arenosillo AERONET site (Huelva, Spain), Q. J. Roy. Meteor. Soc., 133, 795-807, doi:10.1002/qj.54, 2007a.

Toledano, C., Cachorro, V. E., de Frutos, A. M., Sorribas, M., and Prats, N.: Inventory of African Desert Dust Events Over the Southwestern Iberian Peninsula in 2000-2005 with an AERONET Cimel Sun Photometer, J. Geophys. Res., 112, D21201, doi:10.1029/2006JD008307, 2007b.

Trenberth, K. E., Fasullo, J. T., and Kiehl, J.: Earth's Global Energy Budget, B. Am. Meteorol. Soc., 90, 311-323, doi:10.1175/2008BAMS2634.1, 2009.

Valenzuela, A., Olmo, F. J., Lyamani, H., Antón, M., Quirantes, A., and Alados-Arboledas, L.: Classification of aerosol radiative properties during African desert dust intrusions over southeastern Spain by sector origins and cluster analysis, J. Geophys. Res., 117, D06214, doi:10.1029/2011JD016885, 2012a.

Valenzuela, A., Olmo, F. J., Lyamani, H., Antón, M., Quirantes, A., and Alados-Arboledas, L.: Aerosol radiative forcing during African desert dust events (2005-2010) over Southeastern Spain, Atmos. Chem. Phys., 12, 10331-10351, doi:10.5194/acp12-10331-2012, $2012 b$.
Vergaz, R., Cachorro, V. E., de Frutos, A. M., Vilaplana, J. M., and de la Morena, B. A.: Columnar characteristics of aerosols by spectroradiometer measurements in the maritime area of the Cadiz gulf (Spain), Int. J. Climatol., 25, 1781-1804, doi:10.1002/joc.1208, 2005.

Viana, M., Salvador, P., Artiñano, B., Querol, X., Alastuey, A., Pey, J., Latz, A. J., Cabañas, M., Moreno, T., García, S., Herce, M., Diez, P., Romero, D., and Fernández, R.: Assessing the perfomance of methods to detect and quantify African dust in airborne particulates, Environ. Sci. Technol., 44, 8814-8820, doi:10.1021/es1022625, 2010.

Viana, M., Pey, J., Querol, X., Alastuey, A., de Leeuw, F., and Lükewille, A.: Natural Sources of Atmospheric Aerosols Influencing Air Quality Across Europe, Sci. Total Environ., 472, 825833, doi:10.1016/j.scitotenv.2013.11.140, 2014.

Wild, M., Folini, D., Schar, C., Loeb, N., Dutton, E. G., and KönigLanglo, G.: The global energy balance from a surface perspective, Clim. Dynam., 40, 3107-3134, doi:10.1007/S00382-0121569-8, 2013.

Zender, C. S., Bian, H., and Newman, D.: Mineral Dust Entrainment and Deposition (DEAD) model: Description and 1990s dust climatology, J. Geophys. Res., 108, 4416, doi:10.1029/2002JD002775, 2003. 